\title{
Last interglacial sea-level proxies in East Africa and the Western Indian Ocean
}

\author{
Patrick Boyden $^{1}$, Jennifer Weil-Accardo ${ }^{2}$, Pierre Deschamps ${ }^{2}$, Davide Oppo ${ }^{3}$, and Alessio Rovere ${ }^{1}$ \\ ${ }^{1}$ MARUM - Center for Marine Environmental Sciences, University of Bremen, Bremen, Germany \\ ${ }^{2}$ CEREGE, Aix-Marseille Université, CNRS, IRD, Collège de France, Aix-en-Provence, France \\ ${ }^{3}$ Sedimentary Basins Research Group, School of Geosciences, \\ University of Louisiana at Lafayette, Lafayette, Louisiana, USA \\ Correspondence: Patrick Boyden (pboyden@marum.de)
}

Received: 17 November 2020 - Discussion started: 23 November 2020

Revised: 4 March 2021 - Accepted: 12 March 2021 - Published: 20 April 2021

\begin{abstract}
In this paper, we describe a sea-level database compiled using published last interglacial, Marine Isotopic Stage 5 (MIS 5), geological sea-level proxies within East Africa and the Western Indian Ocean (EAWIO). Encompassing vast tropical coastlines and coralline islands, this region has many occurrences of well-preserved last interglacial stratigraphies. Most notably, islands almost entirely composed of Pleistocene reefs (such as Aldabra, the Seychelles) have provided reliable paleo relative sea-level indicators and well-preserved samples for U-series chronology. Other sea-level proxies include uplifted marine terraces in the north of Somalia and Pleistocene eolian deposits notched by the MIS 5 sea level in Mozambique to tidal notches in luminescencelimited eolian deposits in Mozambique. Our database has been compiled using the World Atlas of Last Interglacial Shorelines (WALIS) interface and contains 58 sea-level indicators and 2 terrestrial-limiting data points. The open-access database is available at https://doi.org/10.5281/zenodo.4302244 (Version 1.03; Boyden et al., 2020).
\end{abstract}

\section{Introduction}

The main aim of this paper is to describe a standardized database of geological sea-level proxies, compiled using the tools available through the World Atlas of Last Interglacial Shorelines (WALIS) project (https://warmcoasts.eu/ world-atlas.html, last access: 11 February 2021). WALIS includes an interface that can be used to organize paleo relative sea-level data into a standardized data framework. Once saved in the interface, the data are stored in a MySQL database and can be exported as a multi-sheet spreadsheet that contains data and metadata on sea-level proxies. The exported spreadsheet for the East Africa and Western Indian Ocean (EAWIO) region is the subject of this paper and is available in open-access format here: https://doi.org/10.5281/zenodo.4302244 (Version 1.03; Boyden et al., 2020). In addition, we have included 21 U-series ages compiled within WALIS by Chutcharavan and Dutton (2020).
Pleistocene sea-level records for the coast of East Africa and the Western Indian Ocean (EAWIO) were first described in 1894 by British naturalist William Abbott. During an expedition on board HMS Alert in 1882, Abbott surveyed the Aldabra and Glorieuses island groups, providing the first description of raised coral reefs in this area. It would not be until the 1920s and 1930s when the coastal geomorphology of EAWIO was revisited and new sites were added.

In memory of the extensive contributions made by René Battistini (1927-2017) throughout the EAWIO region, in this paper we will use his proposed Aepyornian (Malagasy Quaternary) nomenclature where appropriate (Battistini, 1984). According to classic definitions, the Aepyornian is punctuated by three major marine transgressions: Tatsimian (Marine Isotopic Stage 7 - MIS 7), Karimbolian (MIS 5e), and Flandrian (Holocene - originally from the Netherlands) (Fig. 1). Guilcher (1954) was the first to describe emerged fossil reefs at $15 \mathrm{~m}$ above sea level (a.s.l.), which he assumed to be Pliocene or Quaternary, on the 


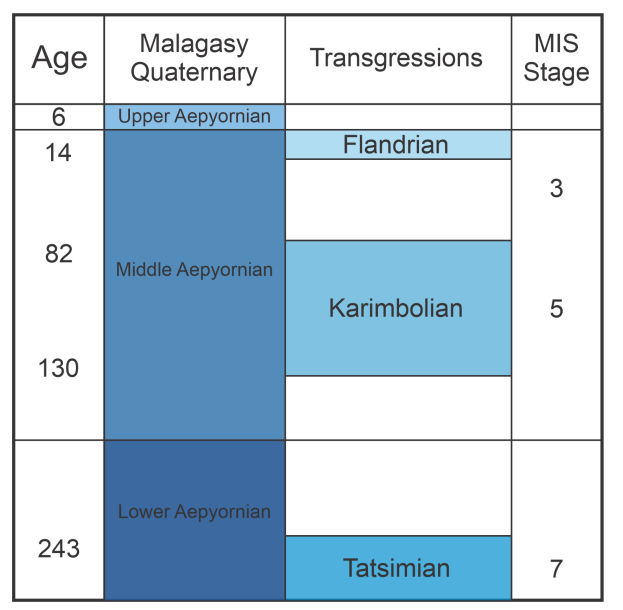

Figure 1. Malagasy Quaternary nomenclature (age is in ka; scheme modified after Battistini, 1984).

northern tip of Madagascar, near the town of Antsiranana. Guilcher (1956) later described two separate emerged reefs at 4 and $12 \mathrm{~m}$ above mean sea level (a.m.s.l.) on the nearby Orangea Peninsula.

During the 1960s and 1970s, the advent of U-Th dating using alpha spectrometry spurred on a new wave of publications in the EAWIO. While these publications offer invaluable information regarding local morphology and stratigraphy, analytical limitations along with focuses deviating from sea-level research prevent many of these early studies from being included within WALIS. For example, Guilcher (1954) and Battistini (1965a) provided two of the first morphological and chronological descriptions of northeastern Madagascar, but it was not until Stephenson et al. (2019) that more accurate elevation and chronological data would be gathered.

In the mid-1950s and 1960s, the Geological Survey of Kenya undertook successive campaigns to map and describe coastal geology (Caswell and Baker, 1953; Thompson, 1956; Williams, 1962). Caswell and Baker (1953) in particular described two marine transgressions along the Kenyan coast, resulting in a succession of coral reef terraces. Battistini (1969) followed with a description of the two most recent marine transgressions in the vicinity of Mombasa and Malindi, with additional detailed stratigraphy of the reef terraces conducted by Crame (1980). Here, the MIS 5e shoreline is primarily dominated by erosional benches, exposing the back-reef lagoonal sediments of the Tatsimian. The emphasis then shifted to the ecology of these paleo-reef environments and away from paleo-sea-level reconstructions (Crame, 1986).

Similarly, in Tanzania, early attempts were made to describe the coastal geomorphology. Stockley (1928) was the first to describe emergent reefs as a dominant lithology of the Zanzibar Archipelago. This was followed much later by Battistini (1966), who described several cropping-out reefs along the central Tanzanian coast, which he attributed to the same transgressive sequences he observed on the northern coast of Madagascar (Tatsimian and Karimbolian). Northwards towards the border with Kenya, Alexander (1969) described a series of emergent, well-developed beach ridges forming three distinct groups; unfortunately, no concrete age was established. Cooke (1974) and Adey (1978) both provide additional stratigraphic descriptions of emergent reef facies on the Tanzanian and Zanzibarian coasts respectively. Again, however, chronological data are lacking and only stratigraphic constraints were provided.

After a long hiatus (Abbott, 1894), Stoddart (1967) began a series of expeditions to the outer, isolated islands of the Seychelles. These small islands, like Assumption, Cosmoledo, and Astove, are primarily made of emergent reef deposits around 4-5 m a.m.s.l. (Bayne et al., 1970a, b; Korotky et al., 1992). Unfortunately, no chronological constraints were produced during these expeditions. In the Granitic Seychelles, Montaggioni and Hoang (1988) provided the first sea-level-specific survey for emerged coralline outcrops adhered to the granitic basement rock with U-series alphaspectrometry ages ranging in elevation from 2 to $7 \mathrm{~m}$ a.m.s.l.

Far to the south, Camoin et al. (1997) and Montaggioni (1972, 1974, 1976, 1982) provide detailed descriptions of the Mascarene Archipelago, home to the islands of Mauritius and Réunion. While mainly volcanic in origin, the Mascarene Archipelago has extensive modern fringing coral reefs and a few occurrences of emerged paleo-reefs (Faure, 1977). Battistini et al. (1976) first described emergent Pleistocene reef sections along the western coast of Mauritius, but for the most part, post-volcanic subsidence means that the majority of Pleistocene outcrops are covered by either more recent eolian sands or Holocene modern coral accumulation (Camoin et al., 1997).

\section{Methods}

\subsection{Types of sea-level indicators}

Within the EAWIO region, we identified six main types of sea-level indicators: coral reef terraces, lagoonal deposits, marine terraces, shallow-water coral reef facies, tidal-inlet facies, and tidal notches. As the region is situated within the tropics and sub-tropics, coralline-related indicators are among the most studied as well as the best chronologically constrained. In Table 1, each indicator's indicative range (IR) and reference water level (RWL) are described. The IR is defined by the upper and lower limits of where the indicator forms in relation to a known datum (e.g., mean sea level MSL); the RWL is the mid-point of the IR. These two values define the indicative meaning for each sea-level proxy, which is used to define where the paleo-sea level was located with respect to the measured position of the landform (Shennan, 1982; Van de Plassche, 2013; Shennan et al., 2015). Additionally, two dune deposits are included as terrestrial-limiting points within WALIS. For these two points, it can only be 
determined that sea level was, at the time of their formation, below the measured elevation of the landform.

\subsection{Surveying techniques}

Very few studies within the EAWIO have the express intent to establish detailed surveys of last interglacial (LIG) sea-level proxies. This is especially true with respect to elevation measurements. Most surveys conducted during the 20th century do not report a methodology used in measuring elevations. It was not until the advent of Global Navigation Satellite Systems (GNSS) and total stations that surveys on many of these remote shorelines could be accurately documented. The elevation measurement techniques used in the studies that we compiled in the database are shown in Table 2. When no accuracy was given for an elevation measurement in the original study, the typical accuracy of the technique was used. Any elevation measurement must be related to a specific sea-level datum (Table 3). Unfortunately, in the literature we surveyed, it was often unclear how most datums were established (e.g., how the highest tide level was calculated at different sites). Instead authors will often state that the elevation is relative to mean sea level or the level of the highest seas. This uncertainty is exacerbated by the large variance in tides within the EAWIO, specifically in the immediate vicinity of the Mozambique Channel (Farrow and Brander, 1971; Kench, 1998). In the database, we therefore try to reflect this uncertainty within the elevation measurement for each proxy.

\subsection{Dating techniques}

Early observations of paleo-shorelines relied primarily on chronostratigraphic constraints to try and piece together a regional narrative. Two formations are primarily used in early studies: the Aldabra Limestone (Aldabra, the Seychelles) and the Karimbolian Limestone (Antsiranana, Madagascar). The Aldabra Limestone is characterized by reef limestones with large corals in growth position. Similarly, the Karimbolian Limestone, first described by Guilcher (1956), refers to massive reefs overlain by red eolianites. Both of these formations have since been chronologically constrained using U-series alpha spectrometry (Thomson and Walton, 1972, and Battistini and Cremers, 1972, respectively).

As with elevation measurement techniques, dating techniques within the EAWIO have advanced dramatically since the first chronologies became available in the early 1960s, thanks to U-series ages from coral samples (Barnes et al., 1956; Thurber et al., 1965). In general terms, U-series ages are derived by measuring the disequilibria between ${ }^{238} \mathrm{U}$, ${ }^{234} \mathrm{U}$, and ${ }^{230} \mathrm{Th}$ radioisotopes (Edwards et al., 2003). The reliability of ${ }^{230} \mathrm{Th}$ ages relies on closed-system behavior that can be compromised by post-depositional processes that lead to a re-mobilization of uranium - or thorium - within the coral skeleton. Several mineralogical and isotopic screening criteria are generally applied to detect any opening of the ${ }^{230} \mathrm{Th}-{ }^{234} \mathrm{U}-{ }^{238} \mathrm{U}$ system. The coral samples should show no evidence of diagenetic alterations such as recrystallization or transformation of primary aragonite to secondary calcite. This is generally assessed by quantification of secondary calcite. In most recent studies, coral samples showing a calcite content of more than $1 \%$ are usually discarded. The uranium content of fossil corals should ordinarily be similar to that of modern ones (about $2.8 \mathrm{ppm}$ ). The back-calculated $\left[{ }^{234} \mathrm{U} /{ }^{238} \mathrm{U}\right]_{0}$ ratio that represents the $\left[{ }^{234} \mathrm{U} /{ }^{238} \mathrm{U}\right]$ ratio at the time of coral growth should reflect the $\left[{ }^{234} \mathrm{U} /{ }^{238} \mathrm{U}\right]$ ratio of seawater. Due to the long oceanic residence time of uranium, this ratio is supposed to be similar to that of modern seawater. For this reason, fossil corals showing a $\left[{ }^{234} \mathrm{U} /{ }^{238} \mathrm{U}\right]_{0}$ ratio that was significantly different from modern seawater were generally discarded (Hamelin et al., 1991; Bard et al., 1991). This isotopic criterion is not always strictly applied since (1) there is much evidence that the $\left[{ }^{234} \mathrm{U} /{ }^{238} \mathrm{U}\right]$ ratio of seawater may have varied through time (see discussion in Chutcharavan et al., 2018) and (2) some models, assuming decay-dependent redistribution of ${ }^{234} \mathrm{Th}$ and ${ }^{230} \mathrm{Th}$, were developed to correct for the "open-system" behavior highlighted by anomalous $\left[{ }^{234} \mathrm{U} /{ }^{238} \mathrm{U}\right]_{0}$ ratios (Thompson et al., 2003; Villemant and Feuillet, 2003). Although these open-system ages are questionable, some of the ages reported here are calculated using such a model (Thompson et al., 2003). Here, we state whether ages were originally reported as closed or open systems. It is important to note that the application of the screening criteria presented here is quite recent and that most of the studies reported in this review were carried out before these criteria became common practice in the U-Th community.

Precision of U-series ages relies upon the analytical method used to measure the isotopic ratios of the sample. U-series alpha-spectrometry dating was the first utilization of ${ }^{238} \mathrm{U}$ decay, detecting and counting the ejected alpha particles. The counting statistics are on the order of a few percent of the ${ }^{230} \mathrm{Th} /{ }^{238} \mathrm{U}$ ratio, resulting in a best-case scenario of $2 \sigma$ internal errors of $\pm 10 \mathrm{ka}$ for an age ranging between 70 and $150 \mathrm{ka}$ and more often than not $2 \sigma$ internal errors closer to $\pm 20 \mathrm{ka}$ (Broecker and Thurber, 1965; Thurber et al., 1965). Therefore, the majority of early chronologies within the EAWIO have limited accuracy and can only be generally assigned to one marine isotope stage. It was not until the 1990s that mass spectrometry, particularly thermal ionization mass spectrometry (TIMS; Edwards et al., 1987, 2003), began to bring down the $2 \sigma$ error allowing MIS substage discernibility. Additional advancements such as multi-collector inductively coupled plasma mass spectrometry (MC-ICPMS) have brought the $2 \sigma$ uncertainties under ideal conditions down to \pm 100 years at $130 \mathrm{ka}$ (Cheng et al., 2013). Besides biogenic carbonates, two terrestriallimiting chronologies from lithified dunes were established through the use of optically stimulated luminescence (OSL). All uncertainties are stated at $2 \sigma$, and, when needed, they 
Table 1. Relative sea-level indicators and their indicative ranges. Exported from Boyden et al. (2020).

\begin{tabular}{|c|c|c|c|}
\hline $\begin{array}{l}\text { Name of RSL } \\
\text { indicator }\end{array}$ & Description of RSL indicator & Description of RWL & Description of IR \\
\hline $\begin{array}{l}\text { Coral reef terrace } \\
\text { (general definition) }\end{array}$ & $\begin{array}{l}\text { Coral-built flat surface, corresponding to shallow-water reef ter- } \\
\text { race to reef crest. The definition of indicative meaning is derived } \\
\text { from Rovere et al. ( } 2016 \mathrm{~b} \text { ), and it represents the broadest pos- } \\
\text { sible indicative range that can be refined with information on } \\
\text { coral living ranges. }\end{array}$ & $\begin{array}{l}\text { (Mean lower low } \\
\text { water }+ \text { breaking } \\
\text { depth }) / 2\end{array}$ & $\begin{array}{l}\text { Mean lower low } \\
\text { water - breaking depth }\end{array}$ \\
\hline Lagoonal deposit & $\begin{array}{l}\text { Lagoonal deposits consist of silty and clayey sediments, fre- } \\
\text { quently characterized by the presence of brackish or marine } \\
\text { water fauna (Rovere et al., 2016b). Usually, lagoon sediments } \\
\text { are horizontally laminated (Zecchin et al., 2004). Definition of } \\
\text { indicative meaning from Rovere et al. (2016b). }\end{array}$ & $\begin{array}{l}\text { (Mean lower low } \\
\text { water }+ \text { modern } \\
\text { lagoon depth) } / 2\end{array}$ & $\begin{array}{l}\text { Mean lower low } \\
\text { water - modern } \\
\text { lagoon depth }\end{array}$ \\
\hline Marine terrace & $\begin{array}{l}\text { "Any relatively flat surface of marine origin" (Pirazzoli, 2005). } \\
\text { Definition of indicative meaning from Rovere et al. (2016b). }\end{array}$ & $\begin{array}{l}\text { (Storm wave swash } \\
\text { height }+ \text { breaking } \\
\text { depth) } / 2\end{array}$ & $\begin{array}{l}\text { Storm wave swash } \\
\text { height }- \text { breaking } \\
\text { depth }\end{array}$ \\
\hline $\begin{array}{l}\text { Shallow-water coral } \\
\text { reef facies }\end{array}$ & $\begin{array}{l}\text { For use when specific reference is given to a modern coral } \\
\text { species and/or morphological occurrence. }\end{array}$ & $\begin{array}{l}\text { Mean low water } \\
\text { springs }\end{array}$ & $\begin{array}{l}\text { Mean low water } \\
\text { springs to depth of } \\
\text { modern living } \\
\text { analogue }\end{array}$ \\
\hline Tidal-inlet facies & $\begin{array}{l}\text { Coarse-grained, thickly bedded, trough cross bedding, herring- } \\
\text { bone cross bedding, multiple scours, Ophiomorpha and } \\
\text { Skolithos trace fossils. }\end{array}$ & -0.5 to $-3.5 \mathrm{~m}$ a.m.s.l. & -0.5 to $-3.5 \mathrm{~m}$ a.m.s.l \\
\hline Tidal notch & $\begin{array}{l}\text { Tidal notches are "indentations or undercuttings cut into rocky } \\
\text { coasts by processes acting in the tidal zone (such as tidal wet- } \\
\text { ting and drying cycles, bioerosion, or mechanical action)" (An- } \\
\text { tonioli et al., 2015). Definition of indicative meaning from Ro- } \\
\text { vere et al. (2016b). }\end{array}$ & $\begin{array}{l}\text { (Mean higher high } \\
\text { water }+ \text { mean lower } \\
\text { low water) } / 2\end{array}$ & $\begin{array}{l}\text { Mean higher high } \\
\text { water - mean lower } \\
\text { low water }\end{array}$ \\
\hline $\begin{array}{l}\text { The data point is a } \\
\text { marine-/terrestrial- } \\
\text { limiting indicator }\end{array}$ & See detailed indicator description. & No RWL available & No IR available \\
\hline
\end{tabular}

have been converted from the $1 \sigma$ values reported in the original papers.

\subsection{Tectonics}

The tectonic setting of paleo relative sea level (PRSL) indicators plays a significant role in their interpretation. Active faulting is found throughout the EAWIO (Fig. 2). For example, the majority of the East Africa coast is sitting atop the Somali Plate that is slowly moving eastwards as the East African Rift Zone (EARZ) slowly opens. Spreading rates in the EARZ decrease from north to south, $4.5 \mathrm{~mm} \mathrm{a}^{-1}$ in Ethiopia to $1.5 \mathrm{~mm} \mathrm{a}^{-1}$ along the Mozambique coastal plain (Stamps et al., 2008), while to the north, the Gulf of Aden is home to the Arabia-Danakil-Somalia triple junction.

When reported in the literature, tectonic categories (stable, uplifting, or subsiding) are recorded within the database as to give the best possible picture of each sea-level-indicator setting. However, the magnitudes of vertical land movements (VLMs) are not explicitly included in the database. The reason behind this decision resides in the fact that the VLM rates that were reported in the literature tend to be derived from several different assumed eustatic sea levels of the LIG. As this is directly tied to sea level, it therefore does not meet the strict "sea-level-independent" criteria for insertion into the database.

\subsection{Paleo relative sea-level estimation}

In order to extract PRSL from measured elevations, the IR and RWL for the measured indicator are needed (Shennan, 1982). The IR relies upon the measurement of modern upper and lower limits of the indicator in relation to an established datum. However, few studies have thoroughly documented the upper and lower limits of the site-specific modern analogue to the indicator. To supplement missing IR and RWL values, Lorscheid and Rovere (2019) introduced a reliable empirical method that uses a global dataset of wave and tide model outputs in conjunction with the morphoand hydrodynamic formation environment of the most common sea-level indicators. This methodology was then packaged into open-access stand-alone software, IMCalc, avail- 
Table 2. Measurement techniques used to survey the elevation of last interglacial shorelines in the EAWIO region. Exported from Boyden et al. (2020).

\begin{tabular}{|c|c|c|}
\hline $\begin{array}{l}\text { Measurement } \\
\text { technique }\end{array}$ & Description & Typical accuracy \\
\hline $\begin{array}{l}\text { Barometric } \\
\text { altimeter }\end{array}$ & $\begin{array}{l}\text { Difference in barometric pressure between a point of known elevation (often } \\
\text { sea level) and a point of unknown elevation. Not accurate and used only rarely } \\
\text { in sea-level studies. }\end{array}$ & $\begin{array}{l}\text { Up to } \pm 20 \% \text { of elevation mea- } \\
\text { surement }\end{array}$ \\
\hline $\begin{array}{l}\text { Differential } \\
\text { GPS }\end{array}$ & $\begin{array}{l}\text { Differential GPS (DGPS) positions acquired in the field and corrected either } \\
\text { in real time or during post-processing with respect to the known position of } \\
\text { a base station or a geostationary satellite system (e.g., OmniSTAR). Accuracy } \\
\text { depends on satellite signal strength, distance from base station, and number of } \\
\text { static positions acquired at the same location. }\end{array}$ & $\begin{array}{l} \pm 0.02 / \pm 0.08 \mathrm{~m} \text {, depending on } \\
\text { survey conditions and instru- } \\
\text { ments used (e.g., single-band } \\
\text { vs. dual-band receivers) }\end{array}$ \\
\hline $\begin{array}{l}\text { Total station or } \\
\text { auto/hand level }\end{array}$ & $\begin{array}{l}\text { Total stations or levels measure slope distances from the instrument to a partic- } \\
\text { ular point and triangulate relative to the } X Y Z \text { coordinates of the base station. } \\
\text { The accuracy of this process depends on how well defined the reference point } \\
\text { is and on the distance of the surveyed point from the base station. Thus, it is } \\
\text { necessary to benchmark the reference station with a nearby tidal datum or use } \\
\text { a precisely (DGPS) known geodetic point. The accuracy of the elevation mea- } \\
\text { surement is also inversely proportional to the distance between the instrument } \\
\text { and the point being measured. }\end{array}$ & $\begin{array}{l} \pm 0.1 / \pm 0.2 \mathrm{~m} \text { for total station } \\
\pm 0.2 / \pm 0.4 \mathrm{~m} \text { for hand level }\end{array}$ \\
\hline Not reported & $\begin{array}{l}\text { The elevation measurement technique was not reported, most probably hand } \\
\text { level or metered tape. }\end{array}$ & $\begin{array}{l}20 \% \text { of the original elevation } \\
\text { reported added in root mean } \\
\text { square form to the sea-level da- } \\
\text { tum error }\end{array}$ \\
\hline
\end{tabular}

Table 3. Sea-level datums reviewed in this study, modified and exported from Boyden et al. (2020).

\begin{tabular}{|c|c|c|c|}
\hline Datum name & Datum description & Datum uncertainty & Reference(s) \\
\hline $\begin{array}{l}\text { High tide } \\
\text { level }\end{array}$ & $\begin{array}{l}\text { Described by Kennedy et al. (2007) as } \\
\text { the swash limit and the extent of fixed } \\
\text { biological indicators, such as mollusks, } \\
\text { having a restricted vertical range. }\end{array}$ & $\begin{array}{l}\text { Per Rees-Jones et al. (2000), accu- } \\
\text { rate to } \pm 2 \mathrm{~m} \text { up to } 15 \mathrm{~m} \text { a.h.s.l. (above } \\
\text { highest sea level) and } \pm 5-10 \mathrm{~m} \text { above } \\
15 \mathrm{~m} \text { a.h.s.l. Uncertainty will be depen- } \\
\text { dent upon measurement method. }\end{array}$ & $\begin{array}{l}\text { Kennedy et al. (2007), } \\
\text { Rees-Jones et al. (2000) }\end{array}$ \\
\hline $\begin{array}{l}\text { Mean low } \\
\text { water springs }\end{array}$ & $\begin{array}{l}\text { "The average of the heights ... of each } \\
\text { pair of successive low waters during } \\
\text { that period of about } 24 \mathrm{~h} \text { in each semi- } \\
\text { lunation (approximately every } 14 \mathrm{~d} \text { ), } \\
\text { when the range of the tide is greatest." }\end{array}$ & $\begin{array}{l}\text { Declared } \pm 0.1 \mathrm{~m} \text { if datum is derived } \\
\text { from } 1 \text { year and } \pm 0.25 \mathrm{~m} \text { if measured } \\
\text { over } 1 \text { month. }\end{array}$ & Baker and Watkins (1991) \\
\hline $\begin{array}{l}\text { Mean sea } \\
\text { level/general } \\
\text { definition }\end{array}$ & $\begin{array}{l}\text { General definition of MSL, with no in- } \\
\text { dications on the datum to which it is re- } \\
\text { ferred. }\end{array}$ & $\begin{array}{l}\text { A datum uncertainty may be established } \\
\text { on a case-by-case basis. }\end{array}$ & \\
\hline Not reported & $\begin{array}{l}\text { The sea-level datum is not reported and } \\
\text { impossible to derive from metadata. }\end{array}$ & $\mathrm{n} / \mathrm{a}$ & \\
\hline
\end{tabular}

n/a means not applicable.

able at https://sourceforge.net/projects/imcalc/ (last access: 6 November 2020) (Lorscheid and Rovere, 2019). In the database we use the upper and lower limits when given by original authors; however, the majority of upper and lower limits for our PRSL points are calculated from the IMCalc software. While IMCalc provides reliable IR and RWL es- timates, accurate surveying of local modern analogues is always preferable (e.g., Dutton et al., 2015). Once the upper and lower limits are determined, WALIS automatically calculates the IR, RWL, PRSL, and PRSL uncertainty, based on the schemes from Rovere et al. (2016a). All of the PRSL elevations in the following text have been calculated from orig- 


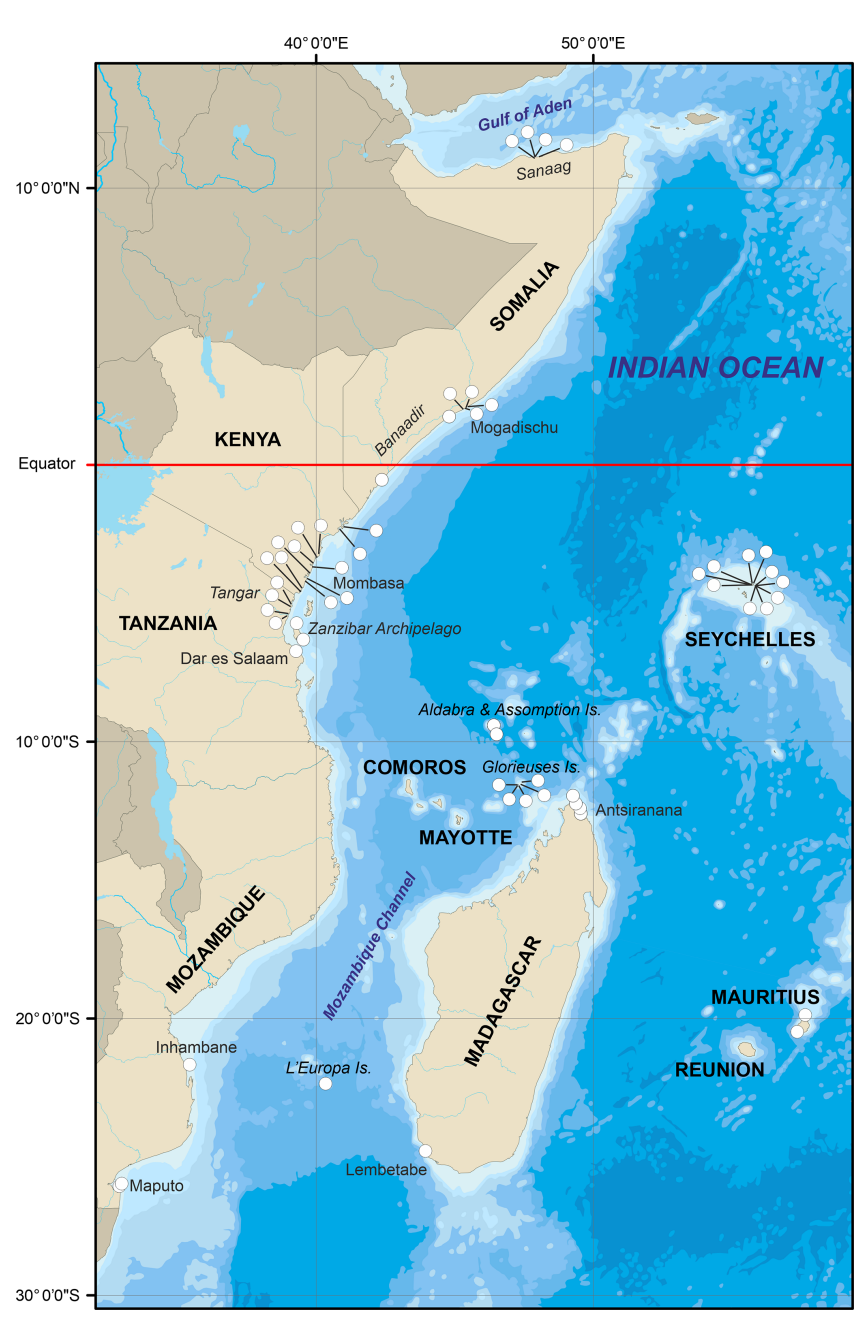

Figure 2. Overview map showing the distribution of PRSL proxies and their respective indicator types. Base map data compiled from Natural Earth; vector and raster map data at https://www. naturalearthdata.com/ (last access: 11 February 2021). An interactive map of the EAWIO data is available in the Supplement.

inally published survey elevations using this methodology in order to standardize their comparison.

\subsection{Uncertainties and data quality}

The aim of WALIS is to provide the most objective evaluation of PRSL data as possible. It therefore must be explicitly noted that each dataset is evaluated by a set of quality control standards that are used throughout the WALIS database (Table 4; Rovere et al., 2020). For the most part, elevation measurements were stated in plain language by the original authors, without describing in detail either measurement methodologies or measurement errors. We have therefore applied our best-estimate errors in these cases based on the standard accuracy of the survey methodologies employed by the original authors (Table 2). When we have done so, we mention this in our evaluation of the RSL proxy quality inside the database.

As discussed previously (Sect. 2.3), ${ }^{238} \mathrm{Th} / \mathrm{U}$ ages are reliant upon the technique and transparency of metadata. While many earlier studies briefly refer to the methodology used, they often provide few, if any, analytical metadata. Within the database, we have accepted all ${ }^{238} \mathrm{Th} / \mathrm{U}$ ages as reported by the original authors and have only reported recalculated ages from Chutcharavan and Dutton (2020) which utilize ${ }^{234} \mathrm{U}$ and ${ }^{238} \mathrm{Th}$ decay constants from Cheng et al. (2013). Each chronological constraint has been rated using the common guidelines provided in the WALIS documentation (Table 5). Additionally, we have reported open-system ages for samples that are derived from mollusks (e.g., Tridacna gigas), which are widely accepted as providing inconsistent ${ }^{238} \mathrm{Th} / \mathrm{U}$ age reliability (e.g., Ayling et al., 2017) and therefore have been assigned a marine isotopic stage designation rather than an outright age. Data with quality higher than 4 (good) are from the most recent studies within this region and are from those who have adopted more rigorous sample screening procedures and have access to the most recent advances in mass spectrometry (e.g., MC-ICPMS).

\section{Sea-level data points}

In total, our database counts 58 sea-level indicators and 2 terrestrial-limiting points (Fig. 3). All sea-level indicators are used to gather an associated PRSL based on the IM associated with the landform. As the EAWIO is a wide geographic area, we describe our data points based on a country-bycountry rationale. We start in the north with Somalia down to Mozambique in the south. We then move offshore to the islands along the Mozambique Channel, including Madagascar. Finally, we review sea-level histories of the Seychelles, Mayotte, Mauritius, and other small minor islands. PRSL indicators are referenced to their respective WALIS RSL ID number as well as to their chronological constraint if available. An additional interactive map of the EAWIO data is available in the Supplement.

\subsection{Somalia}

Knowledge of Somalian Pleistocene sea-level indicators is limited. Only two main regions, the Gulf of Aden coast (Sanaag) and Mogadishu (Banaadir), have been reported in the literature.

\subsubsection{Sanaag}

The northern coast of Somalia (along the Gulf of Aden) is dominated by uplift and the Guban coastal plain. Here, Brook et al. (1996) described a series of four uplifted marine terraces that are intersected by ephemeral stream-carved gorges, locally known as toggas. Mapping of the area was 
Table 4. Quality rating guidelines used for evaluating RPSLs. Exported from WALIS (Rovere et al., 2020).

\begin{tabular}{ll}
\hline Description & Quality rating \\
\hline $\begin{array}{l}\text { Elevation precisely measured and referred to a clear datum and RSL } \\
\text { indicator with a very narrow indicative range. Final RSL uncertainty is } \\
\text { submetric. }\end{array}$ & 5 (excellent) \\
\hline $\begin{array}{l}\text { Elevation precisely measured and referred to a clear datum and RSL } \\
\text { indicator with a narrow indicative range. Final RSL uncertainty is be- } \\
\text { tween } 1 \text { and } 2 \mathrm{~m} .\end{array}$ & 4 (good) \\
\hline $\begin{array}{l}\text { Uncertainties in elevation, datum, or indicative range sum up to a value } \\
\text { of between } 2 \text { and } 3 \text { m. }\end{array}$ & 3 (average) \\
\hline $\begin{array}{l}\text { Final PRSL uncertainty is higher than } 3 \mathrm{~m} . \\
\begin{array}{l}\text { Elevation and/or indicative range must be regarded as very uncertain } \\
\text { due to poor measurement/description/RSL indicator quality. }\end{array}\end{array}$ & 1 (very poor) \\
\hline $\begin{array}{l}\text { There is not enough information to accept the record as a valid RSL } \\
\text { indicator (e.g., marine or terrestrial limiting). }\end{array}$ & 0 (rejected) \\
\hline
\end{tabular}

Table 5. Quality rating guidelines used for evaluating age information. Exported from WALIS (Rovere et al., 2020).

\begin{tabular}{ll}
\hline Description & Quality rating \\
\hline $\begin{array}{l}\text { Very narrow age range, e.g., a few millennia, that allows the attribu- } \\
\text { tion to a specific timing within a substage of MIS 5 (e.g., } 117 \pm 2 \mathrm{ka} \text { ) }\end{array}$ & 5 (excellent) \\
\hline $\begin{array}{l}\text { Narrow age range, allowing the attribution to a specific substage of } \\
\text { MIS 5 (e.g., MIS 5e). }\end{array}$ & 4 (good) \\
\hline $\begin{array}{l}\text { The RSL data point can be attributed only to a generic interglacial } \\
\text { (e.g., MIS 5). }\end{array}$ & 3 (average) \\
\hline Only partial information or minimum age constraints are available. & 2 (poor) \\
\hline $\begin{array}{l}\text { Different age constraints point to different interglacials. } \\
\text { Not enough information to attribute the RSL data point to any Pleis- }\end{array}$ & 0 (rejected) \\
\hline
\end{tabular}

conducted using aerial photographs in conjunction with a series of four transects using altimeter measurements from the field (Brook et al., 1996). Coordinates of samples and terraces in the database were estimated in Google Earth from the original maps published.

Marine terraces are a relatively continuous feature along the northern coast of Somalia and are comprised of fluvial gravels mixed with marine sands that include a significant bioclast component (shell and coral debris). Brook et al. (1996) dated two surface samples with U-series alpha spectrometry from a terrace at $8 \mathrm{~m}$ a.s.l. (WALIS ID 426). These two samples, entered in WALIS as BK96-003-001 and BK96-004-001, returned lower-limit ages of $98 \pm 8$ and $99 \pm 16$ ka respectively (Table 6). Along one of the togga walls, a larger Favites coral was sampled $3 \mathrm{~m}$ below the surface of the $8 \mathrm{~m}$ terrace (indicated as being $10 \mathrm{~m}$ a.s.l. in the original publication). This returned an age of $108 \pm 16 \mathrm{ka}$, indicating that the $8 \mathrm{~m}$ terrace formed following the deposi- tion of the coral, possibly within MIS 5c. Brook et al. (1996) report that the $16 \mathrm{~m}$ terrace, standing above the $8 \mathrm{~m}$ terrace, had fewer sampling opportunities. As a consequence, one surface sample is reported for this terrace (BK96-009-001, WALIS ID 702), which was dated to $145 \pm 22 \mathrm{ka}$, indicating a likely formation age of MIS 5e. The RPSLs for the 8 and $16 \mathrm{~m}$ terrace are calculated at $+9.7 \pm 2.6$ and $+13.7 \pm 3.3 \mathrm{~m}$ respectively.

\subsubsection{Banaadir}

Moving south along the coast, Banaadir province is home to Somalia's capital and largest city: Mogadishu. The city as well as the surrounding area to the north and south is built upon Pleistocene reef deposits (Fig. 4; Carbone and Accordi, 2000). Three RSL index points are described around the capital, one from Brook et al. (1996) and the other two from Carbone and Matteucci (1990) and Carbone and Accordi (2000). 
Table 6. Summary of RSL proxies and terrestrial-limiting points included in the WALIS database.

\begin{tabular}{|c|c|c|c|c|c|c|c|c|c|}
\hline $\begin{array}{l}\text { RSL } \\
\text { ID }\end{array}$ & Site & $\begin{array}{l}\text { Lat } \\
\left({ }^{\circ}\right)\end{array}$ & $\begin{array}{r}\text { Long } \\
\left({ }^{\circ}\right)\end{array}$ & RSL type $^{1}$ & Datum $^{2}$ & $\begin{array}{r}\text { PRSL } \\
(\mathrm{m})\end{array}$ & Age & $\begin{array}{r}\text { RSL } \\
\text { quality }^{3}\end{array}$ & $\begin{array}{r}\text { Age } \\
\text { quality } 3\end{array}$ \\
\hline 149 & Cap d'Ambre & -11.95 & 49.27 & CR terrace & MLWS & $10.7 \pm 1.4$ & U series & 4 & 5 \\
\hline 159 & Cap Miné & -12.24 & 49.38 & CR terrace & MLWS & $8.2 \pm 1.4$ & U series & 4 & 4 \\
\hline 161 & Ankirikiriky Bay & -12.41 & 49.53 & CR terrace & MLWS & $5.7 \pm 1.4$ & U series & 4 & 5 \\
\hline 162 & Irodo & -12.61 & 49.56 & CR terrace & MLWS & $4.1 \pm 1.4$ & U series & 4 & 5 \\
\hline 164 & Glorieuses Is. - C. Vert & -11.59 & 47.29 & CR terrace & MLWS & $5.1 \pm 0.5$ & U series & 4 & 4 \\
\hline 173 & Glorieuses Is. - R. Sud & -11.59 & 47.30 & CR terrace & MLWS & $5.9 \pm 0.5$ & U series & 4 & 3 \\
\hline 174 & Glorieuses Is. - R. Vert & -11.57 & 47.33 & CR terrace & MLWS & $3.9 \pm 2.4$ & U series & 4 & 1 \\
\hline 175 & Glorieuses Is. - I. d. Lys & -11.52 & 47.38 & SW CR & MLWS & $6.4 \pm 0.7$ & U series & 4 & 2 \\
\hline 182 & Cabo Inhaca & -25.97 & 32.99 & Tidal notch & MSL & $5.5 \pm 1.4$ & Luminescence & 1 & 1 \\
\hline 183 & Barreira Vermelha & -26.06 & 32.90 & Terrestrial & MSL & $\mathrm{n} / \mathrm{a}$ & Luminescence & 0 & 3 \\
\hline 184 & Zengueleme & -21.67 & 35.44 & Terrestrial & MSL & $\mathrm{n} / \mathrm{a}$ & Luminescence & 0 & 3 \\
\hline 187 & Kikambala Quarry & -3.92 & 39.78 & CR terrace & MSL & $21.5 \pm 3.6$ & U series & 2 & 3 \\
\hline 189 & Msambweni Quarry & -4.46 & 39.49 & CR terrace & MSL & $20.5 \pm 3.6$ & U series & 2 & 3 \\
\hline 190 & Black Cliff & -4.20 & 39.62 & CR terrace & MSL & $17.5 \pm 3.6$ & U series & 2 & 3 \\
\hline 191 & Shelly Beach Quarry & -4.10 & 39.67 & CR terrace & MSL & $18.5 \pm 3.6$ & U series & 2 & 3 \\
\hline 192 & Takaungu & -3.69 & 39.86 & CR terrace & MSL & $14.5 \pm 3.6$ & U series & 2 & 3 \\
\hline 193 & Watamu - C. Track & -3.30 & 40.10 & CR terrace & MSL & $14.5 \pm 3.6$ & U series & 2 & 3 \\
\hline 194 & Watamu - Sea Cliff & -3.36 & 40.04 & CR terrace & MSL & $11.5 \pm 3.6$ & U series & 2 & 3 \\
\hline 195 & Manda Island - North & -2.24 & 41.00 & CR terrace & MSL & $11.5 \pm 3.6$ & U series & 2 & 3 \\
\hline 196 & Manda Island - South & -2.33 & 40.92 & CR terrace & MSL & $9.5 \pm 3.6$ & U series & 2 & 3 \\
\hline 197 & Kilifi Quarry & -3.56 & 39.91 & CR terrace & MSL & $10.5 \pm 3.6$ & U series & 2 & 3 \\
\hline 198 & Ros Ngomeni & -2.99 & 40.24 & CR terrace & MSL & $9.5 \pm 3.6$ & U series & 2 & 3 \\
\hline 199 & Funzi Island & -4.59 & 39.45 & CR terrace & MSL & $12.5 \pm 3.6$ & U series & 2 & 3 \\
\hline 200 & Mwasaro Village & -4.61 & 39.40 & CR terrace & MSL & $8.5 \pm 4.2$ & U series & 3 & 3 \\
\hline 201 & Diani Beach & -4.29 & 39.60 & CR terrace & MSL & $8.5 \pm 3.6$ & U series & 3 & 3 \\
\hline 207 & Ras Nungwi & -5.72 & 39.30 & CR terrace & HTL & $8.8 \pm 5.6$ & Chronostrat. & 1 & 1 \\
\hline 208 & Kigombe & -5.30 & 39.06 & CR terrace & HTL & $11.0 \pm 2.2$ & Chronostrat. & 1 & 1 \\
\hline 209 & Mwamani Bay & -5.13 & 39.11 & CR terrace & MSL & $9.5 \pm 5.4$ & Chronostrat. & 1 & 1 \\
\hline 210 & Yambe Island & -5.11 & 39.16 & CR terrace & MSL & $11.0 \pm 5.4$ & Chronostrat. & 1 & 1 \\
\hline 211 & Ulenge Island & -5.00 & 39.17 & CR terrace & MSL & $11.0 \pm 5.4$ & Chronostrat. & 1 & 1 \\
\hline 212 & Jambiani - Old & -6.32 & 39.54 & CR terrace & MSL & $25.0 \pm 5.0$ & Chronostrat. & 1 & 1 \\
\hline 213 & Jambiani - Young & -6.32 & 39.54 & CR terrace & MSL & $11.0 \pm 5.1$ & Chronostrat. & 1 & 1 \\
\hline 307 & Glorieuses Is. - Grande & -11.59 & 47.29 & CR terrace & HTL & $4.5 \pm 2.0$ & U series & 2 & 3 \\
\hline 308 & Iles d'Europa & -22.36 & 40.35 & CR terrace & MSL & $4.5 \pm 2.3$ & Chronostrat. & 2 & 0 \\
\hline 348 & Mogadishu - Airport & 2.01 & 45.31 & CR terrace & MSL & $6.4 \pm 1.5$ & U series & 2 & 2 \\
\hline 349 & Mogadishu - Refinery & 1.98 & 45.23 & CR terrace & MSL & $6.4 \pm 1.5$ & U series & 2 & 2 \\
\hline 350 & Fuma Island & -0.55 & 42.38 & CR terrace & MSL & $6.5 \pm 1.5$ & U series & 2 & 2 \\
\hline 351 & Merca & 1.74 & 44.81 & CR terrace & MSL & $6.4 \pm 1.5$ & U series & 2 & 2 \\
\hline 419 & Ras Kalwein - C & 11.11 & 47.98 & MT & MSL & $9.7 \pm 2.6$ & U series & 2 & 2 \\
\hline 426 & Ras Kalwein - A & 11.12 & 47.90 & MT & MSL & $9.7 \pm 2.6$ & U series & 2 & 2 \\
\hline 427 & Plate and Gabriel & -19.88 & 57.66 & CR terrace & NR & $3.1 \pm 2.3$ & U series & 2 & 3 \\
\hline 570 & Inland & -4.36 & 55.83 & SW CR & MLWS & $7.7 \pm 1.0$ & U series & 4 & 5 \\
\hline 572 & Anse Source d'Argent & -4.37 & 55.83 & SW CR & MLWS & $8.4 \pm 1.0$ & U series & 4 & 5 \\
\hline 573 & Anse Source d'Argent & -4.37 & 55.83 & SW CR & MLWS & $4.3 \pm 1.0$ & U series & 4 & 5 \\
\hline 574 & Grande Anse & -4.38 & 55.83 & SW CR & MLWS & $9.1 \pm 1.0$ & U series & 4 & 5 \\
\hline 575 & Turtle Pond & -4.28 & 55.76 & SW CR & MLWS & $7.6 \pm 1.0$ & U series & 4 & 5 \\
\hline 591 & Aldabra & -9.42 & 46.42 & CR terrace & MSL & $9.6 \pm 1.1$ & U series & 1 & 3 \\
\hline 702 & Ras Kalwein - A & 11.11 & 47.90 & MT & MSL & $13.7 \pm 3.3$ & U series & 2 & 2 \\
\hline 703 & Mogadishu & 1.99 & 45.25 & MT & MSL & $3.8 \pm 3.9$ & U series & 2 & 2 \\
\hline 724 & Ras Kankadya & -6.73 & 39.28 & CR terrace & HTL & $7.9 \pm 1.1$ & Chronostrat. & 1 & 1 \\
\hline 731 & Assumption Is. & -9.74 & 46.51 & Tidal inlet & NR & $4.5 \pm 2.5$ & U series & 2 & 3 \\
\hline 733 & Assumption Is. & -9.74 & 46.51 & Lagoon & NR & $2.5 \pm 2.3$ & U series & 2 & 3 \\
\hline 734 & Assumption Is. & -9.74 & 46.51 & CR terrace & NR & $6.6 \pm 2.3$ & U series & 2 & 3 \\
\hline 736 & Glorieuses Is. - I. d. Lys & -11.52 & 47.38 & CR terrace & HTL & $5.5 \pm 2.3$ & U series & 2 & 3 \\
\hline
\end{tabular}


Table 6. Continued.

\begin{tabular}{|c|c|c|c|c|c|c|c|c|c|}
\hline $\begin{array}{l}\text { RSL } \\
\text { ID }\end{array}$ & Site & $\begin{array}{l}\text { Lat } \\
\left({ }^{\circ}\right)\end{array}$ & $\begin{array}{r}\text { Long } \\
\left({ }^{\circ}\right)\end{array}$ & RSL type $^{1}$ & Datum & $\begin{array}{r}\text { PRSL } \\
(\mathrm{m})\end{array}$ & Age & $\begin{array}{r}\text { RSL } \\
\text { quality }^{3}\end{array}$ & $\begin{array}{r}\text { Age } \\
\text { quality }\end{array}$ \\
\hline 937 & Praslin - PR1 & -4.34 & 55.72 & SW CR & MSL & $2.9 \pm 0.4$ & U series & 3 & 3 \\
\hline 938 & Praslin - PR4 & -4.34 & 55.72 & SW CR & MSL & $8.4 \pm 0.4$ & U series & 3 & 1 \\
\hline 939 & Praslin - PR7 & -4.34 & 55.73 & SW CR & MSL & $5.4 \pm 0.4$ & U series & 3 & 3 \\
\hline 940 & Curieuse & -4.28 & 55.73 & SW CR & MSL & $7.4 \pm 0.4$ & U series & 3 & 3 \\
\hline 941 & La Digue & -4.37 & 55.83 & CR terrace & MSL & $2.4 \pm 0.4$ & U series & 3 & 3 \\
\hline 949 & Lembetabe & -24.79 & 43.95 & CR terrace & NR & $3.3 \pm 1.7$ & U series & 3 & 3 \\
\hline 3638 & Choisy & -20.49 & 57.37 & CR terrace & NR & $11.7 \pm 1.7$ & U series & 1 & 2 \\
\hline
\end{tabular}

n/a means not applicable. ${ }^{1} \mathrm{CR}$ terrace - coral reef terrace (general definition), SW CR - shallow-water coral reef facies, MT - marine terrace.

${ }^{2}$ MLWS - mean low water springs, HTL - high tide level, NR - not reported. ${ }^{3}$ Quality ratings are on a scale of 5 (excellent) to 0 (rejected), based on criteria from Rovere et al. (2020).

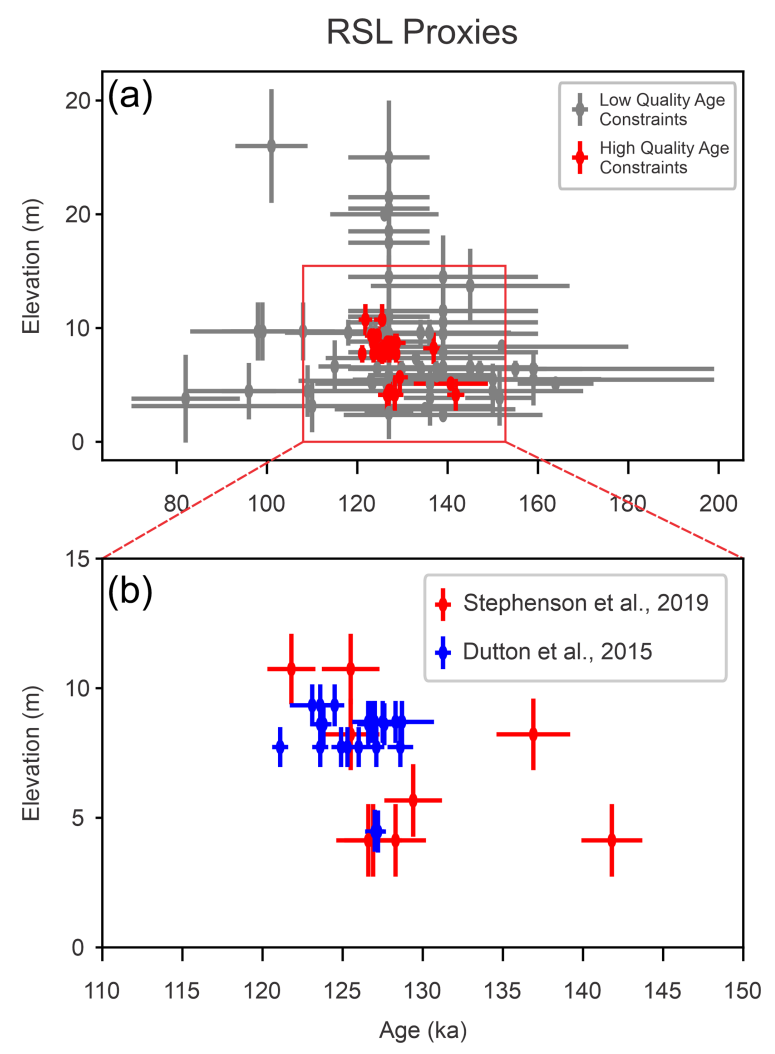

Figure 3. (a) Overview of age and elevation distribution of RPSLs of the East Africa and Western Indian Ocean region. Proxies with age constraints with a quality rating lower than 4 within WALIS are colored grey, and those proxies with a quality rating of 4 or greater are colored red. The elevations refer to paleo relative sea level. "Relative" means that they are still uncorrected for any postdepositional vertical movement, such as tectonics or glacial isostatic adjustment (GIA). (b) The high-quality age constraints are from two areas, northern Madagascar (Stephenson et al., 2019) and the Granitic Seychelles (Dutton et al., 2015).

Brook et al. (1996) describe a recently exposed quarry wall south of Mogadishu displaying a transgressive-regressive se- quence of a coral- and shell-rich sandy layer sandwiched between beach sand deposits and then finally topped by a package of eolian sand. While not in situ, a sample from this coral layer (BK96-010-001, WALIS ID 703) was dated by U-series alpha spectrometry to $82 \pm 12 \mathrm{ka}$. Brook et al. (1996) place the sample at $4 \mathrm{~m}$ above present sea level; we calculate the PRSL to be $+3.8 \pm 3.9 \mathrm{~m}$. Brook et al. (1996) connect this sample to the $2 \mathrm{~m}$ terrace found along the northern coast of Somalia. Carbone and Accordi (2000) describe a Pleistocene reef terrace at, and to the south of, Mogadishu standing 4-6 m high. They describe this terrace as characterized by a fringing reef complex composed of massive Porites, Lobophyllia, Galaxea, and Acropora. While no explicit survey is described, the originally reported $4-6 \mathrm{~m}$ elevation is used to calculate an PRSL of $+6.4 \pm 1.5 \mathrm{~m}$ based on the description of the exposed quarry wall (WALIS IDs 348 and 349; Carbone and Matteucci, 1990). Carbone and Accordi (2000) attribute this sequence to the Pleistocene based on unpublished ages between 105 and $131 \mathrm{ka}$ (errors not stated). Approximately $65 \mathrm{~km}$ down the coast from Mogadishu, near the small city of Merca, Carbone and Accordi (2000) describe a sheltered, well-developed reef with massive corals in growth position. We calculated an PRSL of $+6.4 \pm 1.5 \mathrm{~m}$ and an age correlated to the terraces to the north of between 105 and $131 \mathrm{ka}$ (WALIS ID 351).

\subsection{Kenya}

The coastal region of Kenya can be divided into three sections: northern, central, and southern (Oosterom, 1988). To the north, raised patch reefs are distributed among lagoonal deposits, dune deposits, and beach ridges. Along the central coast, the patch reefs transition into more developed fossil reef terraces. Finally to the south, solitary patch-reefs within lagoonal facies return. Oosterom (1988) tied the development of the central uplifted reefs, unlike those of the north or south, to the topography of the hinterland and the lack of significant fluvial discharge. That being said, marine limestone facies are nearly continuously exposed along the en- 


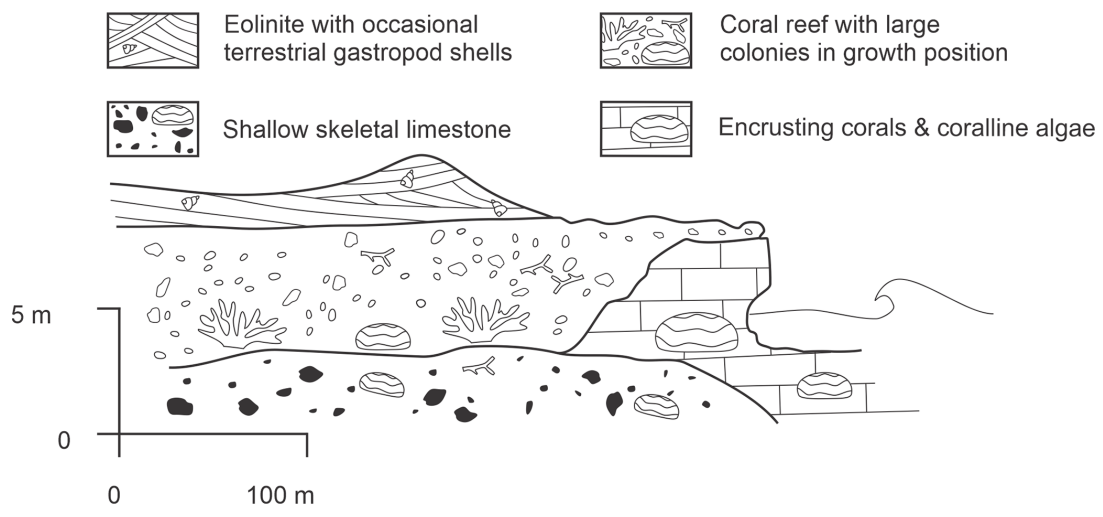

Figure 4. Raised reef and eolinites of southern Somalia (modified after Carbone and Accordi, 2000).

tire Kenyan coastline (Fig. 5), with a maximum elevation of $15 \mathrm{~m}$ (Accordi et al., 2010). While there have been several earlier studies focusing on the Pleistocene deposits along the Kenya coast (Battistini, 1969; Ase, 1981; Braithwaite, 1984), Accordi et al. (2010) are the first to provide vertical positioning data for samples taken. Additionally, Accordi et al. (2010) undertook the most extensive dating of the emerged Kenyan reef sequence. Here, Tridacna gigas were sampled in situ and analyzed using U-series alpha spectrometry. Due to variability in the calculated initial ${ }^{234} \mathrm{U} /{ }^{238} \mathrm{U}$ activity ratio of their samples (compared to the seawater value over the last $120 \mathrm{kyr}$ ), Accordi et al. (2010) considered their samples diagenetically altered and used the open-system model of Scholz et al. (2004) to recalculate ages. Therefore, ages are treated with caution in WALIS, as mollusks (i.e., T. gigas) are susceptible to inconsistent $\mathrm{U}$-series uptake and loss rates when compared to coral specimens (Ayling et al., 2017). The samples were split into three groups by Accordi et al. (2010) according to their apparent elevation and location along the coastline: Group A, Group B, and Group C. Group A is scattered along the southern coast between the towns of Shimoni and Kilifi. The samples were taken from on top of the coral reef terrace within an elevation range of 8-15 $\mathrm{m}$ a.m.s.l. and have an open-system age of $120 \pm 8 \mathrm{ka}$ and an PRSL of between +14.5 and $+21.5 \mathrm{~m}$ (MIS 5e, WALIS IDs 189-192; Table 6). Groups $\mathrm{B}$ and $\mathrm{C}$ are taken from the face of the limestone cliffs 0 and $6 \mathrm{~m}$ a.m.s.l. Group B samples come from the central to northern section of coast between Kilifi and Manda Island, and they have an open-system age of $118 \pm 14 \mathrm{ka}$ and a calculated PRSL of between +9.5 and $+14.5 \mathrm{~m}$ (MIS 5e to 5d, WALIS IDs 193-198; Table 6). Finally, Group $C$ has an open-system age of $100 \pm 8 \mathrm{ka}$ and a calculated PRSL of between +8.5 and $+12.5 \mathrm{~m}$ (MIS $5 \mathrm{c}$ to 5d, WALIS IDs 199-201) and is located along the same section of coast as Group A (Shimoni to Kilifi). Within the database; however, we treat each sample independently in order to separate interpretation from the raw data. Finally, the calculated PRSL uses the indicative range described by Accordi et al. (2010) for T. gigas along the modern Kenyan coast, 3 to $10 \mathrm{~m}$ below mean sea level (b.m.s.l.). In many instances there are poorly preserved massive or branching corals in growth position within this same facies.

\subsection{Tanzania}

Similarly to the littoral of Kenya, Tanzania has nearly continuous marine limestone cliffs cropping out along the coast. Mainly interpreted as fossil back-reef facies, the marine limestones are rich in Halimeda sediment and solitary coral mounds (Arthurton et al., 1999). From north to south, Tanzania's littoral zone can be divided into three regions: Tanga, the Zanzibar Archipelago, and Dar es Salaam.

\subsubsection{Tanga}

The northernmost coastal province of Tanga is characterized by a band of $8 \mathrm{~m}$ high emergent fringing reefs, a similar coastal morphology to that found in southern Kenya. Termed the "Azanian Series" by Stockley (1928), these emergent fringing reefs have been given a Pleistocene age and are abundant in large coral specimens as well as in sponges and echinoids. Unfortunately, like those found in Kenya, the majority of specimens are recrystallized, making U-series dating particularly difficult (Cooke, 1974). We therefore do not include any specific PRSL proxies from the Tanga coastline within the database.

\subsubsection{Zanzibar Archipelago}

The Zanzibar Archipelago comprises two main islands, Pemba and Unguja, along with several smaller islands stretching from the north of Tanzania and south down to Dar es Salaam. The two main islands are generally constructed from extensive deposits of the Azanian Series, forming two distinct terraces. The Older Azanian Limestone is a bivalvegastropod packstone/grainstone, indicative of a shallow lowenergy lagoon setting, which is presently found along the western fringe of Zanzibar (Stockley, 1928). This unit is of unknown age but is described in the literature as being 


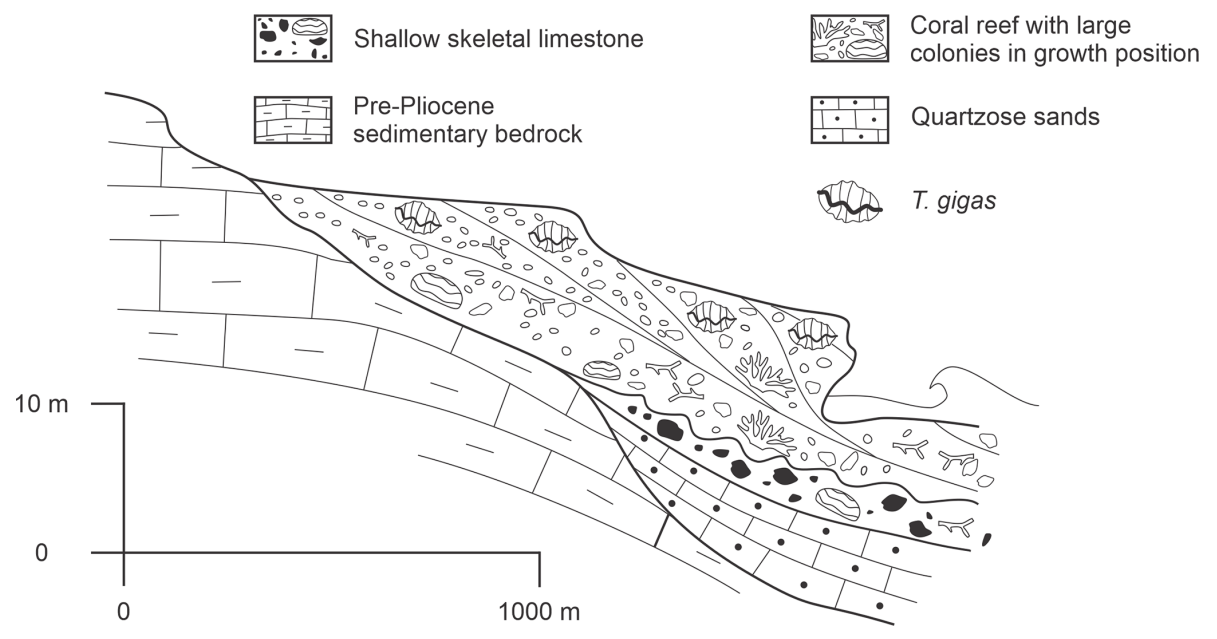

Figure 5. Litholog of emerged reef coast of Kenya (modified after Accordi et al., 2010).

analogous to the $30 \mathrm{~m}$ "back-reef/lagoonal" facies along the Kenyan coast (Abuodha, 2004). Between the higher Older Azanian Limestone and the lower Younger Azanian Limestone is a distinct erosional disconformity, indicating regression. The Younger Azanian Limestone is characterized by abundant coral mounds and bioherms, in growth position, surrounded by coral fragment grainstone. Several studies (e.g., Arthurton et al., 1999; Kourampas et al., 2015) have correlated the terrace formed from the Younger Azanian Limestone to the lower terrace along the coast of Kenya of MIS 5 age (Braithwaite, 1984). Arthurton et al. (1999) argue that the erosional surface of the marine terrace is of late-MIS 5 age because necessary erosion rates for the terrace to be of Holocene age far outpace the observed modern rates on Zanzibar as well as because of the lack of geological evidence for rapid sea-cliff retreat (i.e., talus deposits). Kourampas et al. (2015) provide a descriptive transect of the Jambiani marine terrace from which we calculate an PRSL of $+11 \pm 5.1 \mathrm{~m}$ for MIS 5 (WALIS ID 212). Unfortunately, no current accurate ages are available, and we can only postulate that the lower of the two terraces is correlated to those found in Kenya of MIS 5 age (Battistini et al., 1976).

\subsubsection{Dar es Salaam}

Named after the most populous city in Tanzania, the Dar es Salaam region sits facing the Zanzibar Archipelago. Here, the terraces from Tanga continue. Battistini (1966) provides the most recent description of the Pleistocene sections cropping out along the coast (Fig. 6). At Ras Kankadya, Battistini (1966) describes a coral reef terrace with massive corals in growth position $6-7 \mathrm{~m}$ above high tide disconformably topped by a rubified eolianite. From this coral reef terrace we calculate an PRSL of $+7.9 \pm 1.1 \mathrm{~m}$ for WALIS ID 724 . Chronologically, Battistini (1966) identifies this section as Reef II, which he attributes to the Karimbolian Limestone
(MIS 5; Table 6) that he observed in northern Madagascar (Battistini, 1965b).

Reuter et al. (2010) describe a transgressive wetland sequence along the southern Tanzanian coast, near the town of Lindi. Siting at $21 \mathrm{~m}$ a.m.s.l., the authors identified this deposit, using ${ }^{14} \mathrm{C}$ dating of an Assiminea shell, to $44 \mathrm{ka}$. They argue that this section of coast has undergone $80-110 \mathrm{~m}$ of uplift since the last glacial maximum. While situated near the East African Fracture Zone, this would require a 1.8 to $2.5 \mathrm{~mm} \mathrm{a}^{-1}$ uplift rate, which is not seen in other studies of the surrounding area. Kourampas et al. (2015) carried out an investigation of the neighboring Zanzibar Island and commented on this age, citing that the ${ }^{14} \mathrm{C}$ date is right on the borderline of being reliable (the $2 \sigma$ values are between 48 $41 \mathrm{ka})$ and should be dated using a different methodology that is more appropriate to that age range. Kourampas et al. (2015) also made the observation that Zanzibar has relatively stable $\left(0.1-0.2 \mathrm{~mm} \mathrm{a}^{-1}\right)$ uplift based on observations of more recent speleothems. Unfortunately, this is still a matter of debate as no reliable U-series or other chronology is available from the Tanzanian coast and only chronostratigraphy relating outcrops to neighboring Kenyan deposits is available.

\subsection{Mozambique}

Unlike the coral reef terrace deposits further north, Mozambique's coast is dominated by one of the world's largest coastal dune systems (Botha et al., 2003). Studies reporting on paleo-sea-level indicators from this coast have been limited until relatively recently. In southern Mozambique, near the border with South Africa, two locations, Inhambane and Maputo, have been investigated and chronologically constrained with OSL dating. While not sea-level indicators in their own right, these two locations provide terrestriallimiting points as well as a chronological constraint for a tidal notch. 

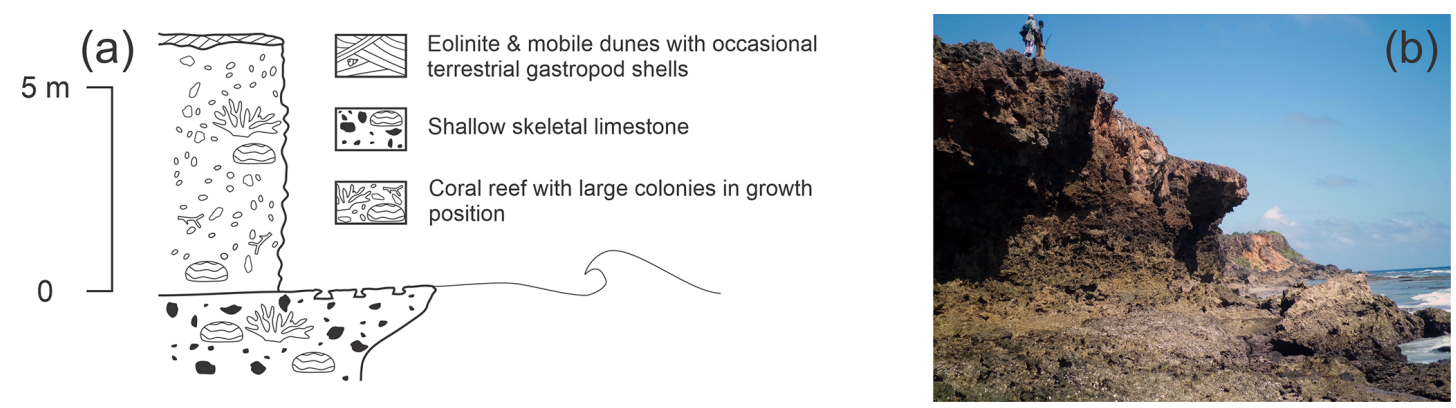

Figure 6. (a) Litholog of emerged reef near Dar es Salaam (modified after Battistini, 1966). (b) Ras Mwanamkuru just south of Ras Kankadya. Exposed Pleistocene reef sitting atop poorly consolidated skeletal limestone. Approximately 10-15 m tall. Photo by Davide Oppo.

\subsubsection{Inhambane}

Bazaruto Island, the largest island of the Bazaruto Archipelago, is comprised of active and inactive dunes migrating across an older, Pleistocene, weathered eolianite core (Armitage et al., 2006). At Zengueleme, on the eastern, bayfacing coast, an exposed $\sim 20 \mathrm{~m}$ tall bluff was described by Armitage et al. (2006). The base of the formation is composed of reddish eolianite dated using OSL to $126 \pm 24 \mathrm{ka}$ (AR06-003-001, associated with WALIS ID 184; Table 6). There is no PRSL for this formation as this is only a terrestrial-limiting point. This eolianite is then covered by a significantly younger dune sequence $(23.8 \pm 4.8 \mathrm{ka}$; Armitage et al., 2006).

\subsubsection{Maputo}

Further south, near the border with South Africa, the Maputo region is home to the capital of Mozambique, Maputo. Just offshore the capital lies the island of Inhaca. An initial survey of Inhaca by Hobday (1977) describes a notch standing 5-6 $\mathrm{m}$ above modern sea level at the northernmost point of the island, Cabo Inhaca. This notch is then referred to again by Armitage et al. (2006), who obtained OSL dates for the eolianite formation the notch is carved into, dating them to $150 \pm 24 \mathrm{ka}$ (AR06-001-001, WALIS ID 182; Table 6). This gives a maximum age constraint to the notch and is therefore inferred to be of MIS 5 age. However, Armitage et al. (2006) indicate issues with the reliability of the OSL age, suggesting that this is possibly an underestimation of the age of the eolianite sedimentation. This is highlighted by the $2 \sigma$ of $\pm 24 \mathrm{ka}$. It should also be noted that Hobday (1977) provides extensive sedimentological descriptions of the calcarenite and dune facies found on Inhaca as well as mentions marine terraces of between 5-6 $\mathrm{m}$ around the island, corresponding to the tidal notch at Cabo Inhaca. Unfortunately, Hobday (1977) does not give specific locations of these terraces, and they are therefore not included in the database.

\subsection{Madagascar}

As the fourth-largest island in the world and with over $4800 \mathrm{~km}$ of coastline in tropical waters and limited terrestrial discharge, Madagascar provides excellent growth conditions for coral reefs. While not documented around the entire island, emergent reefs of Pleistocene age have been described, surveyed, and dated in two main regions of the island: the north and the south.

\subsubsection{North}

Situated at the northern tip of Madagascar, Antsiranana (formerly known as Diego-Suarez) and the surrounding coastline has been the subject of the most recently published PRSL record on the island. Stephenson et al. (2019) revisited sites previously described by Guilcher (1954) and Battistini (1965b). Battistini (1965a) first described two levels of emergent reefs at Cap d'Ambre, one ("Reef I") at $25 \mathrm{~m}$ elevation, which he infers to be older, and "Reef II" at 5-6 m elevation. Unfortunately, no dating was carried out, but, according to Battistini (1965b) Reef I is assumed to be Tatsimian and Reef II is associated with the Karimbolian transgression. Just to the west of Antsiranana, on the Orangea Peninsula, Battistini (1965a) described Reef I at 3-4 m and Reef II at $16 \mathrm{~m}$. While no date at these two sites is available from this first expedition, Battistini et al. (1976) provide a U-series alphaspectrometry age for the nearby Baie des Dunes of between $130 \pm 40$ and $160 \pm 30 \mathrm{ka}$ at $2 \mathrm{~m}$ a.m.s.l. Discrepancies in the elevation between the sites were briefly discussed by Battistini (1965b) with possible explanations including active faulting, tilting, and volcanic subsidence due to the proximity of Mount Ambre.

Stephenson et al. (2019) revisited the Cap d'Ambre and Antsiranana coastlines. Four RSL proxies are extracted from the 13 available open-system U-series dates and DGPS elevations obtained by Stephenson et al. (2019). At Cap d'Ambre, a coral reef terrace stands at $+9.3 \pm 1.2 \mathrm{~m}$ above MLWS with an age of between $121.8 \pm 1.5$ and $125.5 \pm 1.8 \mathrm{ka}$ (ST18002-001 and ST18-001-001, WALIS ID 149; Table 6). This translates to an PRSL of $+10.7 \pm 1.4$ ma.m.s.l. Moving 
south along the eastern shoreline, near Baie des Dunes from Battistini et al. (1976), a coral reef terrace elevation from Cap Miné is recorded at $+6.8 \pm 1.2 \mathrm{~m}$ above MLWS with an age of between $125.5 \pm 1.8$ and $136.9 \pm 2.3 \mathrm{ka}$ (ST18-003001 and ST18-004-001, WALIS ID 159; Table 6). We calculate an PRSL of $8.2 \pm 1.4 \mathrm{~m}$ from Cap Miné. These ages mirror the younger age of Baie des Dunes $(130 \pm 40 \mathrm{ka})$ but are significantly younger than the older $160 \pm 30 \mathrm{ka}$ age from Battistini et al. (1976). The elevation reported by Stephenson et al. (2019) is also higher than that described by Battistini et al. (1976), $6.8 \mathrm{~m}$ vs. $2 \mathrm{~m}$ respectively. As with other datasets, the differences in analytical capability between the 1970s and late 2010s can certainly be a leading cause of these discrepancies in age and in elevation.

Approximately $25 \mathrm{~km}$ south of Cap Miné, Stephenson et al. (2019) observed the coral reef terrace again at Ankirikiriky Bay. Here, the terrace sits at $+4.3 \pm 1.2 \mathrm{~m}$ above MLWS with an age of 129.4 $\pm 1.8 \mathrm{ka}$ (ST18-005-001, WALIS ID 161). This translates to an PRSL of $+5.3 \pm 1.5 \mathrm{~m}$. Finally, further south on the shore of Irodo Bay, the coral reef terrace is observed again, this time at an elevation of $+2.8 \pm 1.2 \mathrm{~m}$ above MLWS and with an age of between $126.6 \pm 2$ and $141.8 \pm 1.9 \mathrm{ka}$ (ST18-005-001 to ST18-009001, WALIS ID 162; Table 6). This correlates to an PRSL of $+4.1 \pm 1.4$ a.m.s.l. The variance in RSL elevations is attributed to possible mantle convective upwelling, creating a dynamic topographic signature (Stephenson et al., 2019).

\subsubsection{South}

To the south of the coastal town of Toliara lies arid Madagascar spiny forestland dominated by thickets of Euphorbia stenoclada and Alluaudia procera. These thickets back the rocky shoreline where Battistini (1964) describes emergent reef sections near the small fishing village of Lembetabe. Unfortunately, this first publication does not provide enough metadata to derive an PRSL proxy. Luckily, however, Battistini et al. (1976) briefly describe the outcrop and provide the first U-series alpha-spectrometry age for this region. The emerged reef, with large in situ corals in growth position, was described at 1-2 ma.m.s.l. with an age of $85 \pm 10 \mathrm{ka}$ (WALIS ID 949, BA76-001-001). We have calculated an PRSL of $+3.3 \pm 1.7 \mathrm{~m}$. This succession is topped by the much younger Lavanonian eolianite that contains continental mollusk shells and fragments of elephant bird shell. Battistini et al. (1976) make the observation that this much younger age compared to other emerged reefs of the Indian Ocean (Veeh, 1966; Montaggioni and Hoang, 1988) may be due to the exposed sections of reef being built in multiple phases.

The reef and sedimentary sequences at Lembetabe are the subject of an ongoing investigation led by the co-authors of this paper, which will include precise measurements, interpretations, and MC-ICPMS U-series ages. The results will be inserted in WALIS as soon as they become available.

\subsection{The Seychelles}

The Seychelles are the largest group of islands in the Western Indian Ocean and represent a stable, far-field study site (Dutton et al., 2015). The main islands themselves are characterized by a granitic core with fringing reefs accreting in the subtidal zone to the bare rock. Outlying islands extend south and to the west, with Aldabra Atoll representing the most westward extent.

\subsubsection{Main islands}

The third-largest island of the Granitic Seychelles archipelago, La Digue, has been the subject of several geomorphological investigations (e.g., Montaggioni and Hoang, 1988; Israelson and Wohlfarth, 1999; Wallinga and Cunningham, 2015). Dutton et al. (2015) describe coral colonies attached to granitic bedrock, similar to those observed within the present subtidal zone. From this, a total of five RSL indicators are included in the database. These are accompanied by $25 \mathrm{U}$-series ages determined using MCICPMS (Dutton et al., 2015). We have included recalculated ages from Chutcharavan and Dutton (2020) in the database, however because these are the only recalculated ages within our database, we refer to the originally reported ages from Dutton et al. (2015) hereafter. Each sample was sub-sampled in triplicate, and ages have been inverse variance-weighted and averaged from the sub-samples (Dutton et al., 2015). All PRSL elevations for Dutton et al. (2015) are determined using the modern analog scheme described by Vyverberg et al. (2018). Inland (WALIS ID 570; Table 6), indicator elevation was measured at $+6.7 \pm 0.2 \mathrm{~m}$ above MLWS and an PRSL was calculated to be $+7.7 \pm 1.0 \mathrm{~m}$. Several in situ corals dated at this locality correlate this PRSL to MIS 5e, averaging $127.3 \pm 0.9 \mathrm{ka}$. Moving out to the coast, the outcrop at Anse Source d'Argent has two subsites (sites $7 \mathrm{a}$ and 8 in Dutton et al., 2015). Here, Site 7a (WALIS ID 572) represents a re-sampling of the earlier Israelson and Wohlfarth (1999) mission to the island. This site sits at $7.4 \pm 0.2 \mathrm{~m}$ above MLWS and the calculated PRSL is $+8.4 \pm 0.2 \mathrm{~m}$. Accepted coral ages from this site average $127.3 \pm 0.4 \mathrm{ka}$. Near Site 7a, Site 8 (WALIS ID 573) has an elevation of $+3.27 \pm 0.2 \mathrm{~m}$ above MLWS and an PRSL of $+4.3 \pm 1.0 \mathrm{~m}$ above MLWS. Site 8 has an average age of $127.1 \pm 0.5 \mathrm{ka}$. On the southeastern coast of La Digue is Grande Anse (Site 11 in Dutton et al., 2015), where in situ corals were surveyed at $+8.14 \pm 0.2 \mathrm{~m}$ above MLWS and an PRSL was calculated at $+9.1 \pm 1.0 \mathrm{~m}$ above MLWS at $124.1 \pm 0.5 \mathrm{ka}$ (WALIS ID 574; Table 6). Finally, to the northwest lies the smaller Curieuse Island where Dutton et al. (2015) describe in situ corals that are similar to the ones found on La Digue at Turtle Pond (Site 19a in Dutton et al., 2015). Corals from this outcrop were dated at an average of $125.2 \pm 0.6 \mathrm{ka}$ at an elevation of $+6.6 \pm 0.2 \mathrm{~m}$ above 
MLWS, equating to an PRSL of $+7.6 \pm 1.0 \mathrm{~m}$ (WALIS ID 575).

\subsubsection{Outlying islands}

Closer to the East African mainland than the Granitic Seychelles archipelago sit the small nearly uninhabited islands of the Aldabra group. The Aldabra group is made up of four islands: Aldabra, Assumption, Astove, and Cosmoledo. Of these islands, three have permanent settlements (one military base and one scientific research station). Aldabra, the largest atoll of the group and its namesake, is constructed predominately from emerged reef terraces (Braithwaite et al., 1973). Two sequential papers (Thomson and Walton, 1972; Braithwaite et al., 1973) provide a detailed morphological, sedimentological, and chronological survey of Aldabra Atoll. Two terraces, one at $8 \mathrm{~m}$ and another at $4 \mathrm{~m}$ a.m.s.l., were described (Braithwaite et al., 1973). These terraces comprise well-preserved, often fairly large corals in growth position (Fig. 7b). In situ samples from the upper coral terrace were collected and returned an average U-series alphaspectrometry age of $127 \pm 18 \mathrm{ka}$ (TH72-001-001 to TH72008-001, WALIS ID 591; Table 6) (Thomson and Walton, 1972). We calculate an PRSL of $+8.5 \pm 1.1 \mathrm{~m}$ for this upper coral terrace.

Lying $30 \mathrm{~km}$ to the south of the main island of Aldabra Atoll, Assumption Island was the subject of a more recent survey by Korotky et al. (1992). On Assumption Island, three marine terraces are described; 2-3, 4-8, and 10-14 m a.m.s.l. Within this general morphological context, Korotky et al. (1992) provide a detailed stratigraphic description with corresponding U-series ages (unknown if alpha or mass spectrometry) from a 4-6 m high exposed section of the "Marine Terrace III" on the southern coast of the island (Fig. 7a, c). At the base of this outcrop, a $1 \mathrm{~m}$ thick section of lagoonal cross-bedded calcarenite is present and was dated to $127 \pm 5.4$ ka (KO92-002-001, WALIS ID 733; Table 6). Lying above this is a $1.9 \mathrm{~m}$ thick section of coral reef with in situ (possibly in growth position) massive corals dated to $115 \pm 3.6 \mathrm{ka}$ (KO92-001-001, WALIS ID 734; Table 6). The reef section is disconformably terminated and is topped by a $1.5 \mathrm{~m}$ thick cross-bedded section of calcarenite with isolated rounded pebbles and cobbles, dated to $96 \pm 6 \mathrm{ka}$ (KO92-003-001, WALIS ID 731; Table 6). The whole section is capped by a thin remnant layer of eolianite of unknown age. From this section, three RSL index points can be extracted. The oldest, the lagoonal deposit, has a maximum age of $127 \pm 5.4 \mathrm{ka}$ and an PRSL estimation of $2.5 \pm 2.3 \mathrm{~m}$. Next, the reef deposit represents an PRSL of $+6.6 \pm 2.3 \mathrm{~m}$ at $115 \pm 3.6 \mathrm{ka}$. Finally, the tidal-marsh deposit indicates an PRSL of $+6.0 \pm 3.0 \mathrm{~m}$ with a minimum age of $96 \pm 6 \mathrm{ka}$.

\subsection{Mauritius}

Dominating the central Indian Ocean, the island nation of Mauritius consists of two main island groups: the Chagos and the Mascarene archipelagos. Here, Battistini et al. (1976) and Montaggioni $(1972,1976)$ describe emergent reefs along the majority of the Mauritius coastline as well on the two small islets to the north of the main island: Île Plate and Îlot Gabriel. The reefs are generally characterized as framestone with large in situ Acropora, Pocilloporidae, and Faviidae corals (Fig. 8). The morphological description of the reefs was accompanied by one U-series alpha-spectrometry age from Veeh (1966). This index stands between +1.5 and $+2 \mathrm{~m}$ a.m.s.l., representing an PRSL of $3.1 \pm 2.3 \mathrm{~m}$ at $110 \pm 40 \mathrm{ka}$ (VE66-012-001, WALIS ID 427; Table 6). A second reef sequence is situated higher, between +5 to $+6 \mathrm{~m}$ a.m.s.l.; however, this section is not dated and therefore not included in the database.

On the main island of Mauritius, Battistini et al. (1976) describe emergent fringing reefs with corals in growth position at around $10 \mathrm{~m}$ a.m.s.l. This indicator is difficult to locate as the position is described as in the village of Tamarin as well as the "Rock of the Virgin Mary" in the village of Choisy along the southwestern coast of Mauritius. In the database, we use the best estimated position for the Rock of the Virgin Mary as the indicator's position. Using IMCalc, we calculated an PRSL of $11.7 \pm 1.7 \mathrm{~m}$. This is related to one Useries alpha-spectrometry age from Battistini et al. (1976) of $120 \pm 40 \mathrm{ka}$ (BA76-003-001, WALIS ID 3638; Table 6).

\subsection{Islands in the Mozambique Channel}

In the Mozambique Channel, which separates Madagascar from mainland Africa, lies the small volcanic Comoros Archipelago (Comoros and Mayotte) as well as four of the five French Scattered Islands (Îles Éparses): the Glorieuses, Juan de Nova, Bassas da India, and Europa. Detailed elevations and ages of Pleistocene stratigraphic sequences are only available for the Glorieuses islands, with limited reference to a Pleistocene-Holocene contact on Mayotte.

\subsubsection{Glorieuses islands}

Sitting approximately $200 \mathrm{~km}$ west of the northern tip of Madagascar, the Glorieuses are made up of two main islands: Grande Glorieuse and Île du Lys (Guillaume et al., 2013). Battistini et al. (1976) provided the first U-series alpha-spectrometry ages for the island. On Grande Glorieuse, an emergent reef with corals in growth position was sampled and an age of $150 \pm 40 \mathrm{ka}$ (BA76-005-001, WALIS ID 307; Table 6) was established. This reef was described at $3 \mathrm{~m}$ above high tide level (HTL), which translates to an PRSL of $+4.5 \pm 2.0 \mathrm{~m}$ above HTL. To the west of the main island, Île du Lys is significantly smaller but has the better preserved Pleistocene record of the two islands. Here, Battistini et al. (1976) describe an emergent reef outcrop between +3 

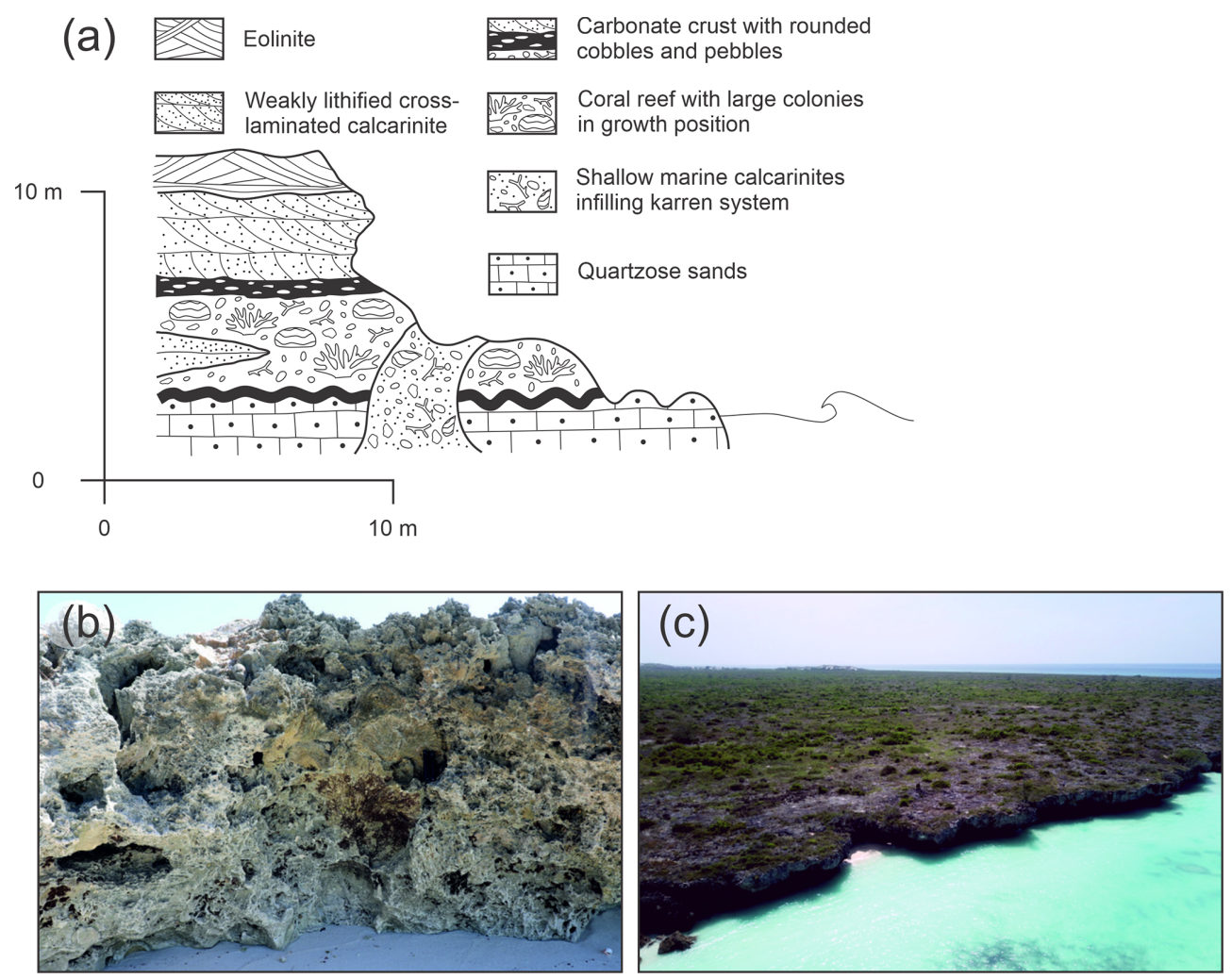

Figure 7. (a) Litholog of Marine Terrace II (modified after Korotky et al., 1992). (b) Lower part of the Pleistocene reef complex at Aldabra. (c) Aerial view of the Pleistocene reef at Assumption Island. Photos by Alessio Rovere.

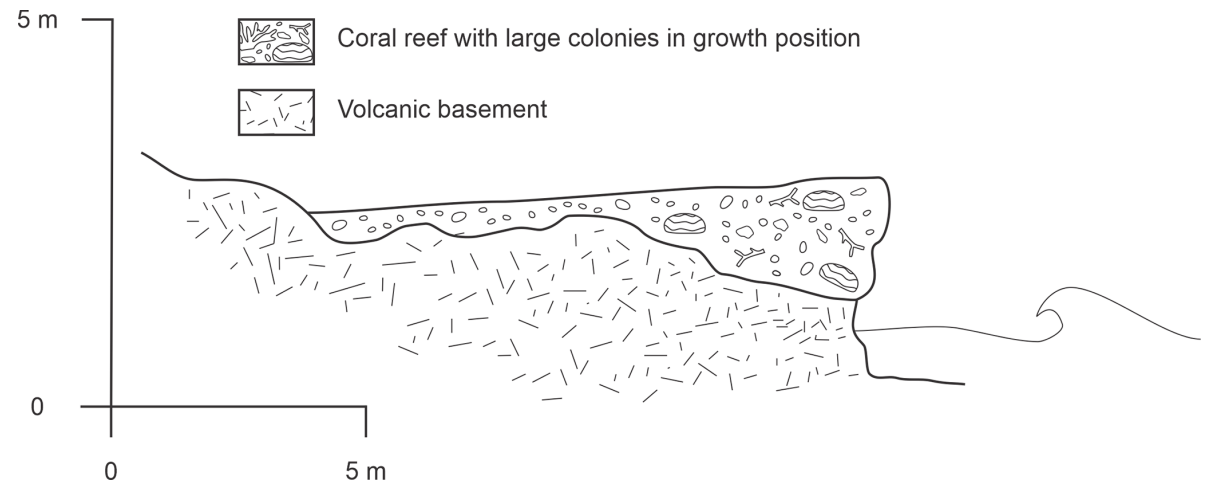

Figure 8. Raised reef platform of Île Plate (modified after Montaggioni, 1982).

to $+5 \mathrm{~m}$ above HTL. A U-series age of $159 \pm 40 \mathrm{ka}$ was obtained for a sample of in situ coral (BA76-006-001; Table 6).

Guillaume et al. (2013) returned to the islands and provided 19 new U-series alpha-spectrometry ages for the islands. From these ages, four RSL proxies were established. At Cap Vert on the central west coast of Grande Glorieuse, sampled corals have elevations of between $+3.8 \pm 0.2$ and $+3.5 \pm 0.2 \mathrm{~m}$ above MLWS and ages of between $123.3 \pm 12.6$ and $140 \pm 8.2 \mathrm{ka}$ (GU13-001 to GU13-004, WALIS ID 164; Table 6). This equates to an PRSL of $+5.1 \pm 0.5 \mathrm{~m}$.
Just off the southern tip of the island, at Rocher Sud, one coral sample was dated to $127 \pm 4.6 \mathrm{ka}$ (GU13-005001, WALIS ID 173; Table 6) from an outcrop $+4.4 \pm 0.2 \mathrm{~m}$ above MLWS equating to an PRSL of $+5.9 \pm 0.5 \mathrm{~m}$. GU13006-001 was also sampled from the same outcrop at Rocher Sud; however the age of $137 \mathrm{ka}$ was rejected by the authors because of high initial ${ }^{234} \mathrm{U} /{ }^{238} \mathrm{U}$ ratios (Guillaume et al., 2013). Similarly to Rocher Sud, the slightly larger Rocher Vert sits roughly $3 \mathrm{~km}$ to the northeast of the island emerging from the modern reef flat. Two samples were taken from Rocher Vert (GU13-007-001 and GU13-008-001, 
WALIS ID 174; Table 6); however both samples were rejected for overestimating age based on especially high initial ${ }^{234} \mathrm{U} /{ }^{238} \mathrm{U}$ ratios. The maximum elevations of the reef facies from Rocher Vert were nonetheless used within the database, and an PRSL of $+6.3 \pm 0.5 \mathrm{~m}$ was calculated.

Île du Lys is home to the island group's most extensive elevated reef flat exposure. Unfortunately, only one sample, GU13-014-001, passed the calcite screening process of Guillaume et al. (2013), and it has an age of $124 \pm 6.4 \mathrm{ka}$ (WALIS ID 175; Table 6). Two different lithologies separated by a disconformity are described. The lower of the two facies transitions from a Halimeda floatstone to a framestone dominated by branching and a few massive corals in growth position. GU13-014-001 was sampled from this floatstone layer. Above this, a discontinuity separates the overlying bed of coarse Halimeda-rich grainstone with occasional coralline bioclasts interpreted as an overwash deposit. The upper elevation of the lower unit is used as an RSL proxy and results in an PRSL of $+6.4 \pm 0.7 \mathrm{~m}$ a.m.s.l.

\subsubsection{Mayotte}

The island of Mayotte is characterized by a tall rugged volcanic core surrounded by an almost continuous barrier reef. Camoin et al. (1997) conducted a reef drilling campaign to ascertain the growth patterns of the reef during the Holocene. At the base of the Holocene core section, -16 to $-20 \mathrm{~m}$ below the reef surface, a basal contact with what is believed to be a Pleistocene reef sequence was found. Unfortunately, samples from this section of the core had undergone significant diagenesis and no definitive age was found (Camoin et al., 1997). Due to the lack of chronological constraints, this is not included in the database.

\section{Further details}

\subsection{Last interglacial sea-level fluctuations}

Sea-level fluctuations during the LIG and subsequent rises and falls within MIS 5 have been alluded to by several studies in the EAWIO region. For example Montaggioni and Hoang (1988) argue for two peaks, one between 139-133 ka and another at about $123 \mathrm{ka}$ based on the distribution of their U-series alpha-spectrometry ages across the Granitic Seychelles. Brook et al. (1996) also identify apparent fluctuations in LIG sea level. Both the $8 \mathrm{~m}$ terrace and $16 \mathrm{~m}$ terrace they identified along the northern coast of Somalia (Sect. 3.1.1) are most likely from the LIG. Here, there is stratigraphic evidence that regression occurred following the formation of the $16 \mathrm{~m}$ terrace before the $8 \mathrm{~m}$ terrace incised this alluvial unit. However, the magnitude of this fluctuation is overshadowed by two caveats: this coastal region is tectonically active and the $16 \mathrm{~m}$ terrace age is base on one sample (BK96-009-001, WALIS ID 702) that Brook et al. (1996) call "extremely questionable."
It was not until recently that surveying methodology and chronological constraints achieved an accuracy that enables the documentation of such fluctuations (Fig. 3a, b). Vyverberg et al. (2018) conducted a multidisciplinary investigation of the Seychelles record of Dutton et al. (2015). Across multiple outcrops around the main islands, reef growth is interrupted by discontinuities within the paleo-record. Vyverberg et al. (2018) argue that this interruption in coral growth is the possible result of subaerial exposure during a fall in sea level or a stillstand. Braithwaite (2020) revisited Braithwaite et al. (1973) and describes evidence of variations in sea level during the LIG on Aldabra. However, both studies conclude that higher-resolution dating is needed in order to confirm this hypothesis.

\subsection{Other interglacials}

Within the EAWIO basin, older, less preserved marine deposits have been described in the literature. Unfortunately, the majority of these deposits have not been confidently dated. The only dated deposit is found on the central Kenyan coast near south Kilifi where Battistini et al. (1976) describe an emerged reef $2 \mathrm{~m}$ above HTL with a U-series age of $240 \pm 80 \mathrm{ka}$.

\section{Data availability}

The East Africa and the Western Indian Ocean database is available at https://doi.org/10.5281/zenodo.4302244 (Version 1.03; Boyden et al., 2020). The description of the database fields can be found at https://doi.org/10.5281/zenodo.3961543 (Rovere et al., 2020).

\section{Future research directions}

The recent studies of Dutton et al. (2015), Vyverberg et al. (2018), and Stephenson et al. (2019) show the potential for high-resolution data acquisition within the EAWIO (Fig. 3b). Many earlier studies have described localities that are promising for LIG sea-level-specific studies, future studies should revisit these sites with modern surveying and chronological methodologies to achieve more accurate constraints. For example, long stretches of raised coral reef terraces along the East African coast extending south from Mogadishu have the potential to provide an uninterrupted sequence of reef stratigraphy across hundreds of kilometers. Many others of the coralline islands have been described by original geographic surveys and have not been revisited to properly survey or date elevated reef deposits (e.g., Astove Island, Bayne et al., 1970a, b, and Cosmoledo Atoll, Bayne et al., 1970a) and have the potential to provide additional high-resolution RSL proxies. 
Supplement. The supplement related to this article is available online at: https://doi.org/10.5194/essd-13-1633-2021-supplement.

Author contributions. PB compiled the database with extensive help from JWA on translating older French publications into English. AR is the main developer of WALIS. PB wrote the initial manuscript, with significant input from JWA and AR. Further input on the manuscript was provided by PD and DO.

Competing interests. The authors declare that they have no conflict of interest.

Special issue statement. This article is part of the special issue "WALIS - the World Atlas of Last Interglacial Shorelines". It is not associated with a conference.

Acknowledgements. The data used in this study were compiled in WALIS, a sea-level database interface developed by the ERC Starting Grant "WARMCOASTS" (ERC-StG-802414), in collaboration with the PALSEA (PAGES-INQUA) working group. The database structure was designed by Alessio Rovere, Deirdre Ryan, Thomas Lorscheid, Andrea Dutton, Peter Chutcharavan, Dominik Brill, Nathan Jankowski, Daniela Mueller, Melanie Bartz, Evan Gowan, and Kim Cohen. The data points used in this study were contributed to WALIS by Patrick Boyden, with Peter Chutcharavan providing assistance with some U-series data entry.

Financial support. This research has been supported by the Deutsche Forschungsgemeinschaft (Excellence Cluster "EXC 2077: The Ocean Floor - Earth's Uncharted Interface", project no. 390741603), the European Research Council (grant no. ERCStG802414), and the French National Institute for Sustainable Development (IRD).

Review statement. This paper was edited by Matteo Vacchi and reviewed by two anonymous referees.

\section{References}

Abbott, W. L.: Notes on the natural history of Aldabra, Assumption and Glorioso islands, Indian Ocean, Proceedings of the United States National Museum, Washington D.C., USA, 1894.

Abuodha, J. O. Z.: Geomorphological evolution of the southern coastal zone of Kenya, J. Afr. Earth Sci., 39, 517-525, 2004.

Accordi, G., Brilli, M., Carbone, F., and Voltaggio, M.: The raised coral reef complex of the Kenyan coast: Tridacna gigas U-series dates and geological implications, J. Afr. Earth Sci., 58, 97-114, 2010.

Adey, W. H.: Coral reef morphogenesis: a multidimensional model, Science, 202, 831-837, 1978.
Alexander, C. S.: Beach ridges in northeastern Tanzania, Geogr. Rev., 59, 104-122, 1969.

Antonioli, F., Lo Presti, V., Rovere, A., Ferranti, L., Anzidei, M., Furlani, S., Mastronuzzi, G., Orru, P. E., Scicchitano, G., Sannino, G., Spampinato, C. R., Pagliarulo, R., Deiana, G., de Sabata, E., Sansò, P., Vacchi, M., and Vecchio, A.: Tidal notches in Mediterranean Sea: a comprehensive analysis, Quaternary Sci. Rev., 119, 66-84, https://doi.org/10.1016/j.quascirev.2015.03.016, 2015.

Armitage, S. J., Botha, G. A., Duller, G. A. T., Wintle, A. G., Rebêlo, L. P., and Momade, F. J.: The formation and evolution of the barrier islands of Inhaca and Bazaruto, Mozambique, Geomorphology, 82, 295-308, 2006.

Arthurton, R., Brampton, A., Kaaya, C., and Mohamed, S.: Late Quaternary coastal stratigraphy on a platform-fringed tropical coast: a case study from Zanzibar, Tanzania, J. Coast. Res., 15, 635-644, 1999.

Ase, L. E.: Studies of Shores and Shore Displacement on the Southern Coast of Kenya - Especially in Kilifi District, Geogr. Ann. A, 63, 303-310, 1981.

Ayling, B. F., Eggins, S., McCulloch, M. T., Chappell, J., Grün, R., and Mortimer, G.: Uranium uptake history, open-system behaviour and uranium-series ages of fossil Tridacna gigas from Huon Peninsula, Papua New Guinea, Geochim. Cosmochim. Ac., 213, 475-501, 2017.

Baker, R. and Watkins, M.: Guidance notes for the determination of mean high water mark for land title surveys., Tech. rep., New Zealand Institute of Surveyors, Wellington, New Zealand, 1991.

Bard, E., Fairbanks, R. G., Hamelin, B., Zindler, A., and Hoang, C. T.: Uranium-234 anomalies in corals older than 150,000 years, Geochim. Cosmochim. Ac., 55, 2385-2390, 1991.

Barnes, J., Lang, E., and Potratz, H.: Ratio of ionium to uranium in coral limestone, Science, 124, 175-176, 1956.

Battistini, R.: Etude geomorphologique de l'extreme sud de Madagascar, Editions Cujas, Paris, France, 1964 (in French).

Battistini, R.: L'extrême-Sud de Madagascar, L'Information Géographique, 29, 83-84, 1965a (in French).

Battistini, R.: Le quaternaire littoral de l'extrême Nord de Madagascar, Quaternaire, 2, 133-144, 1965b (in French).

Battistini, R.: Le Quaternaire littoral des environs de Dar-es-Salam (Tanzanie), Bulletin de l'Association française pour l'étude du quaternaire, 3, 191-201, 1966 (in French).

Battistini, R.: Le Quaternaire du Littoral Kenyan entre Mombasa et Malindi, Quaternaire, 6, 229-238, 1969 (in French).

Battistini, R.: Mise au point sur la terminologie du Quaternaire malgache, Madagascar (Tananarive), 9-25, 1984 (in French).

Battistini, R. and Cremers, G.: Geomorphology and vegetation of Iles Glorieuses, Atoll Research Bulletin, 159, 1-10, 1972.

Battistini, R., Lalou, C., and Elbez, G.: Datation par la methode 230TH 234U du Pleistocene moyen marin de Madagascar et des iles voisines, Bulletin de la Société Géologique de France, 1976 (in French).

Bayne, C., Cogan, B., Diamond, A., Frazier, J., Grubb, P., Hutson, A., Poore, M., Stoddart, D. R., and Taylor, J.: Geography and ecology of Cosmoledo Atoll, Atoll Research Bulletin, 136, 37 56, 1970a.

Bayne, C., Cogan, B., Diamond, A., Frazier, J., Grubb, P., Hutson, A., Poore, M., Stoddart, D. R., and Taylor, J.: Geography and ecology of Astove, Atoll Research Bulletin, 136, 83-99, $1970 \mathrm{~b}$. 
Botha, G. A., Bristow, C. S., Porat, N., Duller, G., Armitage, S. J., Roberts, H. M., Clarke, B. M., Kota, M. W., and Schoeman, P.: Evidence for dune reactivation from GPR profiles on the Maputaland coastal plain, South Africa, Geological Society, London, Special Publications, 211, 29-46, 2003.

Boyden, P., Weil Accardo, J., Deschamps, P., Oppo, D., and Rovere, A.: Database of last interglacial sea level proxies in the East Africa and Western Indian Ocean Region (Version 1.03), Zenodo, https://doi.org/10.5281/zenodo.4302244, 2020.

Braithwaite, C.: Last Interglacial changes in sea level on Aldabra, western Indian Ocean, Sedimentology, 67, 3236-3258, 2020.

Braithwaite, C. J., Taylor, J., and Kennedy, W. J.: The evolution of an atoll: the depositional and erosional history of Aldabra, Philos. T. Roy. Soc. B, 266, 307-340, 1973.

Braithwaite, C. J. R.: Depositional History of the Late Pleistocene Limestones of the Kenya Coast, J. Geol. Soc., 141, 685-699, 1984.

Broecker, W. S. and Thurber, D. L.: Uranium-Series Dating of Corals and Oolites from Bahaman and Florida Key Limestones, Science, 149, 58-60, https://doi.org/10.1126/science.149.3679.58, 1965.

Brook, G. A., Cowart, J. B., and Ford, D. C.: Raised Marine Terraces Along the Gulf of Aden Coast of Somalia, Phys. Geogr., 17, 297-312, 1996.

Camoin, G., Colonna, M., Montaggioni, L., Casanova, J., Faure, G., and Thomassin, B.: Holocene sea level changes and reef development in the southwestern Indian Ocean, Coral Reefs, 16, 247-259, 1997.

Carbone, F. and Accordi, G.: The Indian Ocean Coast of Somalia, Mar. Pollut. Bull., 41, 141-159, 2000.

Carbone, F. and Matteucci, R.: Outline of Somali Quaternary Coral Reefs, Reef Encounters, 7, 12-14, 1990.

Caswell, P. and Baker, B.: The Geology of the Mombasa-Kwale area, Report, Geological Survey of Kenya, Nairobi, Kenya, 1953.

Cheng, H., Lawrence Edwards, R., Shen, C.-C., Polyak, V. J., Asmerom, Y., Woodhead, J., Hellstrom, J., Wang, Y., Kong, X., Spötl, C., Wang, X., and Calvin Alexander, E.: Improvements in $230 \mathrm{Th}$ dating, 230Th and $234 \mathrm{U}$ half-life values, and U-Th isotopic measurements by multi-collector inductively coupled plasma mass spectrometry, Earth Planet. Sc. Lett., 371-372, 8291, 2013.

Chutcharavan, P. M. and Dutton, A.: A Global Compilation of Useries Dated Fossil Coral Sea-level Indicators for the Last Interglacial Period (MIS 5e), Earth Syst. Sci. Data Discuss. [preprint], https://doi.org/10.5194/essd-2020-381, in review, 2020.

Chutcharavan, P. M., Dutton, A., and Ellwood, M. J.: Seawater 234U/238U recorded by modern and fossil corals, Geochim. Cosmochim. Ac., 224, 1-17, 2018.

Cooke, H.: The coastal geomorphology of Tanga, Tanzania, Geogr. Rev., 64, 517-535, 1974.

Crame, J.: Succession and Diversity in the Pleistocene Coral Reefs of the Kenya Coast, Palaeontology, 23, 1-37, 1980.

Crame, J. A.: Late Pleistocene molluscan assemblages from the coral reefs of the Kenya coast, Coral Reefs, 4, 183-196, 1986.

Dutton, A., Webster, J. M., Zwartz, D., Lambeck, K., and Wohlfarth, B.: Tropical tales of polar ice: evidence of Last Interglacial polar ice sheet retreat recorded by fossil reefs of the granitic Seychelles islands, Quaternary Sci. Rev., 107, 182-196, 2015.
Edwards, L. R., Chen, J. H., and Wasserburg, G. J.: 238U-234U230Th-232Th Systematics and the Precise Measurement of Time Over the Past 500,000 Years, Earth Planet. Sc. Lett., 81, 175192, 1987.

Edwards, L. R., Gallup, C. D., and Cheng, H.: Uranium-series dating of marine and lacustrine carbonates, Rev. Mineral. Geochem., 52, 363-405, 2003.

Farrow, G. and Brander, K.: Tidal studies on Aldabra, Philos. T. Roy. Soc. B, 260, 93-121, 1971.

Faure, G.: Distribution of coral communities on reef slopes in the Mascarene Archipelago, Indian Ocean, Marine Research in Indonesia, 17, 73-97, 1977.

Guilcher, A.: Les recifs coralliens du nord-ouest de Madagascar, Bulletin de l'Association de Géographes Français, 31, 147-156, 1954 (in French).

Guilcher, A.: Etude géomorphologique des récifs coralliens du Nord-Ouest de Madagascar, Ann. Inst. Oceanogr. (Paris), 33, 65136, 1956 (in French).

Guillaume, M., Reyss, J.-L., Pirazzoli, P. A., and Bruggemann, J. H.: Tectonic stability since the last interglacial offsets the Glorieuses Islands from the nearby Comoros archipelago, Coral Reefs, 32, 719-726, 2013.

Hamelin, B., Bard, E., Zindler, A., and Fairbanks, R. G.: 234U/238U mass spectrometry of corals: How accurate is the UTh age of the last interglacial period?, Earth Planet. Sc. Lett., 106, 169-180, 1991.

Hobday, D.: Late Quaternary sedimentary history of Inhaca Island, Mozambique, S. Afr. J. Geol., 80, 183-191, 1977.

Israelson, C. and Wohlfarth, B.: Timing of the Last-Interglacial High Sea Level on the Seychelles Islands, Indian Ocean, Quaternary Res., 51, 306-316, 1999.

Kench, P.: Physical processes in an Indian Ocean atoll, Coral Reefs, 17, 155-168, 1998.

Kennedy, D., Tannock, K., Crozier, M., and Rieser, U.: Boulders of MIS 5 age deposited by a tsunami on the coast of Otago, New Zealand, Sediment. Geol., 200, 222-231, 2007.

Korotky, A., Rajigaeva, N., and Kovalukh, N.: Relief and Deposits of Assumption Island, Seychelles, Indian Ocean, J. Coast. Res., 8, 788-796, 1992.

Kourampas, N., Shipton, C., Mills, W., Tibesasa, R., Horton, H., Horton, M., Prendergast, M., Crowther, A., Douka, K., and Faulkner, P.: Late Quaternary speleogenesis and landscape evolution in a tropical carbonate island: Pango la Kuumbi (Kuumbi Cave), Zanzibar, Int. J. Speleol., 44, 293-314, 2015.

Lorscheid, T. and Rovere, A.: The indicative meaning calculatorquantification of paleo sea-level relationships by using global wave and tide datasets, Open Geospatial Data, Software and Standards, 4, 10, https://doi.org/10.1186/s40965-019-0069-8, 2019.

Montaggioni, L. F.: Essai de chronologie relative des stationnements marins quaternaries a l'lle Maurice (Archipel des Mascareignes, Ocean Indien), CR. Acad. Sci. Paris, D, 274, 29362939, 1972 (in French).

Montaggioni, L. F.: Coral reefs and quaternary shorelines in the Mascarene archipelago, Indian Ocean, in: Proc. 2nd Int. Coral Reef Symp, 22 June-2 July 1973, Brisbane, Australia, vol. 1, 579-593, 1974.

Montaggioni, L. F.: Histoire géologique des récifs coralliens de l'archipel des Mascareignes, Biologie marine et exploitation 
des ressources de l'océan Indien occidental. ORSTOM, Paris, Travaux et Documents de l'ORSTOM, 47, 113-128, 1976 (in French).

Montaggioni, L. F.: Pleistocene marine depositional environments from Mauritius Island, Indian Ocean, Geobios, 15, 161-179, 1982.

Montaggioni, L. F. and Hoang, C.: The last interglacial high sea level in the granitic Seychelles, Indian Ocean, Palaeogeogr. Palaeocl., 64, 79-91, 1988.

Oosterom, A. P.: The Geomorphology of Southeast Kenya, Thesis, Wageningen Agricultural University, Wageningen, the Netherlands, 1988.

Pirazzoli, P. A.: Marine Terraces, Springer Netherlands, Dordrecht, the Netherlands, 632-633, 2005.

Rees-Jones, J., Rink, W., Norris, R., and Litchfield, N.: Optical luminescence dating of uplifted marine terraces along the Akatore Fault near Dunedin, South Island, New Zealand, New Zeal. J. Geol. Geop., 43, 419-424, 2000.

Reuter, M., Piller, W. E., Harzhauser, M., Berning, B., and Kroh, A.: Sedimentary Evolution of a Late Pleistocene Wetland Indicating Extreme Coastal Uplift in Southern Tanzania, Quaternary Res., 73, 136-142, 2010.

Rovere, A., Raymo, M. E., Vacchi, M., Lorscheid, T., Stocchi, P., Gómez-Pujol, L., Harris, D. L., Casella, E., O’Leary, M. J., and Hearty, P. J.: The analysis of Last Interglacial (MIS 5e) relative sea-level indicators: Reconstructing sealevel in a warmer world, Earth-Sci. Rev., 159, 404-427, https://doi.org/10.1016/j.earscirev.2016.06.006, $2016 \mathrm{a}$.

Rovere, A., Stocchi, P., and Vacchi, M.: Eustatic and Relative Sea Level Changes, Current Climate Change Reports, 2, 221-231, $2016 b$.

Rovere, A., Ryan, D., Murray-Wallace, C., Simms, A., Vacchi, M., Dutton, A., Lorscheid, T., Chutcharavan, P., Brill, D., Bartz, M., Jankowski, N., Mueller, D., Cohen, K., and Gowan, E.: Descriptions of database fields for the World Atlas of Last Interglacial Shorelines (WALIS) (Version 1,0), Zenodo, https://doi.org/10.5281/zenodo.3961543, 2020.

Scholz, D., Mangini, A., and Felis, T.: U-series dating of diagenetically altered fossil reef corals, Earth Planet. Sc. Lett., 218, 163-178, 2004.

Shennan, I.: Interpretation of Flandrian sea-level data from the Fenland, England, Proceedings of the Geologists' Association, 93, 53-63, 1982.

Shennan, I., Long, A. J., and Horton, B. P.: Handbook of sea-level research, John Wiley \& Sons, Chichester, UK, 2015.

Stamps, D. S., Calais, E., Saria, E., Hartnady, C., Nocquet, J.M., Ebinger, C. J., and Fernandes, R. M.: A kinematic model for the East African Rift, Geophys. Res. Lett., 35, L05304, https://doi.org/10.1029/2007GL032781, 2008.
Stephenson, S. N., White, N. J., Li, T., and Robinson, L. F.: Disentangling interglacial sea level and global dynamic topography: Analysis of Madagascar, Earth Planet. Sc. Lett., 519, 61-69, 2019.

Stockley, G.: The geology of Zanzibar and Pemba islands, Report, Government Printer, Zanzibar, Tanzania, 1928.

Stoddart, D. R.: Summary of the ecology of coral islands north of Madagascar, Atoll Research Bulletin, 118, 53-61, 1967.

Thompson, A.: Geology of the Malindi area, Report, Geological Survey of Kenya, Nairobi, Kenya, 1956.

Thompson, W. G., Spiegelman, M. W., Goldstein, S. L., and Speed, R. C.: An open-system model for U-series age determinations of fossil corals, Earth Planet. Sc. Lett., 210, 365-381, https://doi.org/10.1016/S0012-821X(03)00121-3, 2003.

Thomson, J. and Walton, A.: Redetermination of chronology of Aldabra Atoll by $230 \mathrm{Th} / 234 \mathrm{U}$ dating, Nature, 240, 145-146, 1972.

Thurber, D. L., Broecker, W. S., Blanchard, R. L., and Potratz, H. A.: Uranium-series ages of Pacific atoll coral, Science, 149, 55-58, 1965.

Van de Plassche, O.: Sea-level Research: a Manual for the Collection and Evaluation of Data: a Manual for the Collection and Evaluation of Data, Springer, Dordrecht, the Netherlands, 2013.

Veeh, H. H.: Th230/U238 and U234/U238 ages of Pleistocene high sea level stand, J. Geophys. Res., 71, 3379-3386, 1966.

Villemant, B. and Feuillet, N.: Dating open systems by the 238U234U-230Th method: application to Quaternary reef terraces, Earth Planet. Sc. Lett., 210, 105-118, 2003.

Vyverberg, K., Dechnik, B., Dutton, A., Webster, J. M., Zwartz, D., and Portell, R. W.: Episodic reef growth in the granitic Seychelles during the Last Interglacial: implications for polar ice sheet dynamics, Mar. Geol., 399, 170-187, 2018.

Wallinga, J. and Cunningham, A. C.: Luminescence Dating, Uncertainties and Age Range, Springer Netherlands, Dordrecht, the Netherlands, 440-445, 2015.

Williams, L. A. J.: Geology of the Hadu-Fundi Isa area north of Malindi, Report, Geological Survey of Kenya, Nairobi, Kenya, 1962.

Zecchin, M., Nalin, R., and Roda, C.: Raised Pleistocene marine terraces of the Crotone peninsula (Calabria, southern Italy): facies analysis and organization of their deposits, Sediment. Geol., 172, 165-185, 2004. 